\title{
A revision of Onychelmis Hinton, 1941 (Coleoptera: EImidae), with description of new species, DNA barcoding and notes on the geography of the genus
}

\author{
Marek LINSKÝ ${ }^{1}$, Zuzana ČIAMPOROVÁ-ZAŤOVIČOVÁ ${ }^{2} \&$ Fedor ČIAMPOR Jr ${ }^{3, *}$ \\ ${ }^{1,2,3}$ Zoology Lab, Institute of Botany, Plant Science and Biodiversity Centre, \\ Slovak Academy of Sciences, Dúbravská cesta 9, SK-84523, Bratislava, Slovakia. \\ ${ }^{1}$ Department of Zoology, Faculty of Natural Science, Comenius University, \\ Mlynská dolina B-1, SK-84215 Bratislava, Slovakia. \\ ${ }^{2}$ Department of Ecology, Faculty of Natural Science, Comenius University, \\ Mlynská dolina B-1, SK-84215 Bratislava, Slovakia. \\ *Corresponding author: f.ciampor@savba.sk \\ ${ }^{1}$ Email: marek.linsky@gmail.com \\ 22Email: zuzana.zatovicova@savba.sk \\ 1 (1) https://orcid.org/0000-0001-7206-2380 \\ 2 (1) https://orcid.org/0000-0003-0506-6212 \\ 3 (으 https://orcid.org/0000-0001-6269-3592

\footnotetext{
${ }^{1}$ urn:Isid:zoobank.org:author:E2AC74B9-FA5F-4D43-9168-4513D3E80A04

${ }^{2}$ urn:lsid:zoobank.org:author:8D6A1FDB-06AB-44A7-B1F9-3FC86B7C9804
} \\ ${ }^{3}$ urn:lsid:zoobank.org:author:977CE415-B2E7-45DA-9DBE-B6D7CCCC58E4
}

\begin{abstract}
The genus Onychelmis Hinton, 1941 was for a long time regarded as a small taxon with only three known species distributed in the Andes. A study of new material from Ecuador, using morphological and molecular data, has resulted in the discovery of five new species: Onychelmis lenkae sp. nov., O. lobata sp. nov., O. minor sp. nov., O. onorei sp. nov. and O. splendida sp. nov. We also revised the entire genus and redescribed the three known species, O. longicollis (Sharp, 1882), O. leleupi Delève, 1968 and O. whiteheadi Spangler \& Santiago, 1991. Habitus photographs of adults are provided, together with line drawings of male and female genitalia, and schematic illustrations of the distribution of femoral tomentum for each species. DNA sequences for barcoding the COI mtDNA fragment were used to support species delimitation and to suggest possible relationships among species. The revision includes a key to adults of all species of Onychelmis and notes on the biogeography of the genus, with an updated distribution map.
\end{abstract}

Keywords. Elminae, South America, Andes, taxonomy, DNA barcoding.

Linský M., Čiamporová-Zat'ovičová Z. \& Čiampor Jr F. 2021. A revision of Onychelmis Hinton, 1941 (Coleoptera: Elmidae), with description of new species, DNA barcoding and notes on the geography of the genus. European Journal of Taxonomy 739: 1-35. https://doi.org/10.5852/ejt.2021.739.1263 


\section{Introduction}

The Elmidae Curtis, 1830 is a moderately large cosmopolitan family of aquatic beetles, which includes around 1500 known species classified in almost 150 genera (Jäch et al. 2016). The elmids are common inhabitants of various lotic habitats, and they also form an important component of aquatic assemblages (Cayrou et al. 2000) and serve as valuable ecological indicators (e.g., Compin \& Céréghino 2003).

Numerous recently published descriptions of new species document the high diversity of Elmidae in the Neotropical region (e.g., Manzo \& Archangelsky 2015; Passos et al. 2015; Čiampor et al. 2016; Shepard \& Barr 2016; Barr 2018; Martínez-Román et al. 2019; Polizei et al. 2020), and although our knowledge of the elmid fauna of the tropics improves and interest in riffle beetle taxonomy grows, the information on the real diversity of the family is still far from complete.

This study examines the type material of two of the three known species of Onychelmis Hinton, 1941 and freshly collected material from Ecuador, the country in South America with the highest biodiversity per $\mathrm{km}^{2}$ (Sites et al. 2003). Monte \& Mascagni (2012) described ten new elmid species and recognized 59 species for Ecuador classified in 19 genera. Since then, an expedition to this country has yielded extensive material, from which several new species (Linský et al. 2019) and one new genus have so far been described (Čiampor et al. 2019). Additionally, Polizei \& Barclay $(2018,2019)$ recorded two known species of the genus Hintonelmis Spangler, 1966 and described one new species of Cylloepus Erichson, 1847 from Ecuador. Onychelmis was, for a long time, regarded as a small genus with only three species distributed along the Andes in Central and South America. The genus was erected by Hinton (1941) with the type species Onychelmis longicollis (Sharp, 1882), originally described from a single specimen found in Panama (Sharp 1882). Additional material, collected by M.N. Leleup in Ecuador, was described as a new species, Onychelmis leleupi Delève, 1968. The third species, Onychelmis whiteheadi Spangler \& Santiago, 1991, was collected in 1984 in Colombia.

Most works that deal with Elmidae taxonomy rely on morphological diagnostic characters. In this study, we employed DNA barcoding, a useful method for species delimitation (e.g., Hayashi et al. 2013; Čiampor et al. 2016). Molecular methods or the knowledge of genital structure are often necessary for accurate identification of minute insects. Without this information, a lot of species can be reliably determined only to the genus level. However, a common practice is to identify them as the known species from a respective region, which can result in undervaluation of local biodiversity and distortion of species distribution data. Moreover, the DNA-based methods often represent a faster and more universal approach for species delimitation than morphology, accelerating our understanding of biodiversity richness. This is especially important with respect to increasing deforestation and habitat loss in tropical regions due to human activities.

In this work, the combination of morphological and molecular data is used, which allows us to identify a surprisingly high diversity of Onychelmis species within a relatively small geographic area. We describe five new species, and almost triple the known number of species of the genus. The three known species are redescribed and relationships within the genus are briefly discussed. Additionally, we have summarized data on the distribution of the genus and compiled an identification key for adults of all known species.

\section{Material and methods}

The studied material was collected by net sampling in smaller streams flowing in primary or degraded forest. Larvae and adults were fixed in pure alcohol directly in the field. Specimens for the morphological study were cleaned and examined under a Leica M205C stereo microscope at magnifications up to $160 \times$. Male genitalia and ovipositors were studied as temporary glycerine slides at magnifications up to 
$600 \times$, using a Leica DM1000 light microscope. Drawings were made with a drawing tube. Photographs of habitus were made using a Leica M205C with a Nikon D3s digital camera attached. Image stacks were combined using Zerene Stacker software and finalised in Adobe Photoshop CS5. The beginning and end of label texts are indicated using double quotation marks ("'); a double slash (//) separates the data on different labels. Morphological terms generally follow Kodada et al. (2016).

Metric characters were measured with an ocular grid to the nearest $0.05 \mathrm{~mm}$. Abbreviations used in the text:

$\mathrm{CL}=$ combined body length (measured from anterior margin of pronotum to elytral apices)

$\mathrm{EL}=$ elytral length

$\mathrm{EW}=$ maximum elytral width

$\mathrm{HW}=$ head width with eyes

$\mathrm{ID}=$ interocular distance

$\mathrm{PL}=$ pronotal length

$\mathrm{PW}=$ maximum pronotal width

The DNA was isolated from whole specimens using the DNeasy Blood and Tissue Kit (Qiagen) according to the manufacturer's protocol or by phenol-chloroform extraction. A fragment of the $5^{\prime}$ end of the mitochondrial gene for cytochrome c oxidase subunit I ( $\operatorname{cox} I)$ was amplified with primers LCO1490 and HCO2198 (Folmer et al. 1994). Amplification products were purified and sequenced from both sides in Macrogen Europe Inc. (Amsterdam, Netherlands) and subsequently assembled and edited in Sequencher ver. 5.1. For the phylogenetic analysis, 20 sequences from larvae and adults were used, one of which was downloaded from GenBank. The measurement of the genetic distance using the K2P model, maximum likelihood tree and bootstrap support (1000 replicates) were performed in MEGA X software ver. 10.0.4 (Kumar et al. 2018). The best-fitted substitution model (TN93+G) was selected by jModelTest 2 (Darriba et al. 2012). The final tree was edited in FigTree ver. 1.4.2 and Adobe Illustrator. Two sequences of Ictelmis martae Čiampor et al., 2019 and three of Notelmis sp. were used for outgroup rooting. Sequences were sent to GenBank (accession numbers: KR134432; MF322597-MF322604; MF322606-MF322612; MF322614; MT762804-MT762811) and BOLD databases. The dataset DSELMONYCH, with all information on sequences, was created in BOLD and was assigned with a DOI: https://doi.org/10.5883/DS-ELMONYCH.

\section{Repositories}

$\mathrm{CCB}=$ Coleoptera Collection Plant Science \& Biodiversity Centre SAS (Bratislava, Slovakia)

EMEC = Essig Museum of Entomology, University of California (Berkeley, California, USA)

MZSP = Museu de Zoologia da Universidade de São Paulo (São Paulo, Brazil)

NHM $=$ Natural History Museum (London, UK)

$\mathrm{NMNH}=$ National Museum of Natural History (Washington, DC, USA)

PUCE = Pontifical Catholic University of Ecuador (Quito, Ecuador)

All Ecuadorean specimens belong to PUCE, but presently are, for a long-term loan, deposited in CCB.

\section{Results}

\section{DNA barcoding and species delimitation}

Final coxl barcoding fragments were $620 \mathrm{bp}$ long with no ambiguous sites or indels. The phylogenetic tree (Fig. 1) produced by maximum likelihood from twenty specimens of Onychelmis revealed seven well recognized molecular taxonomic units (species) in Onychelmis. The intraspecific distance was between $0-1.1 \%$, the highest difference between conspecific samples was recorded in $O$. leleupi, the species with the widest reported distribution. The interspecific distance ranged from 4.4 to $10.5 \%$. The species of Onychelmis were distanced by 11.9-14.9\% from Ictelmis and by 18.1-20.4\% from Notelmis samples. 


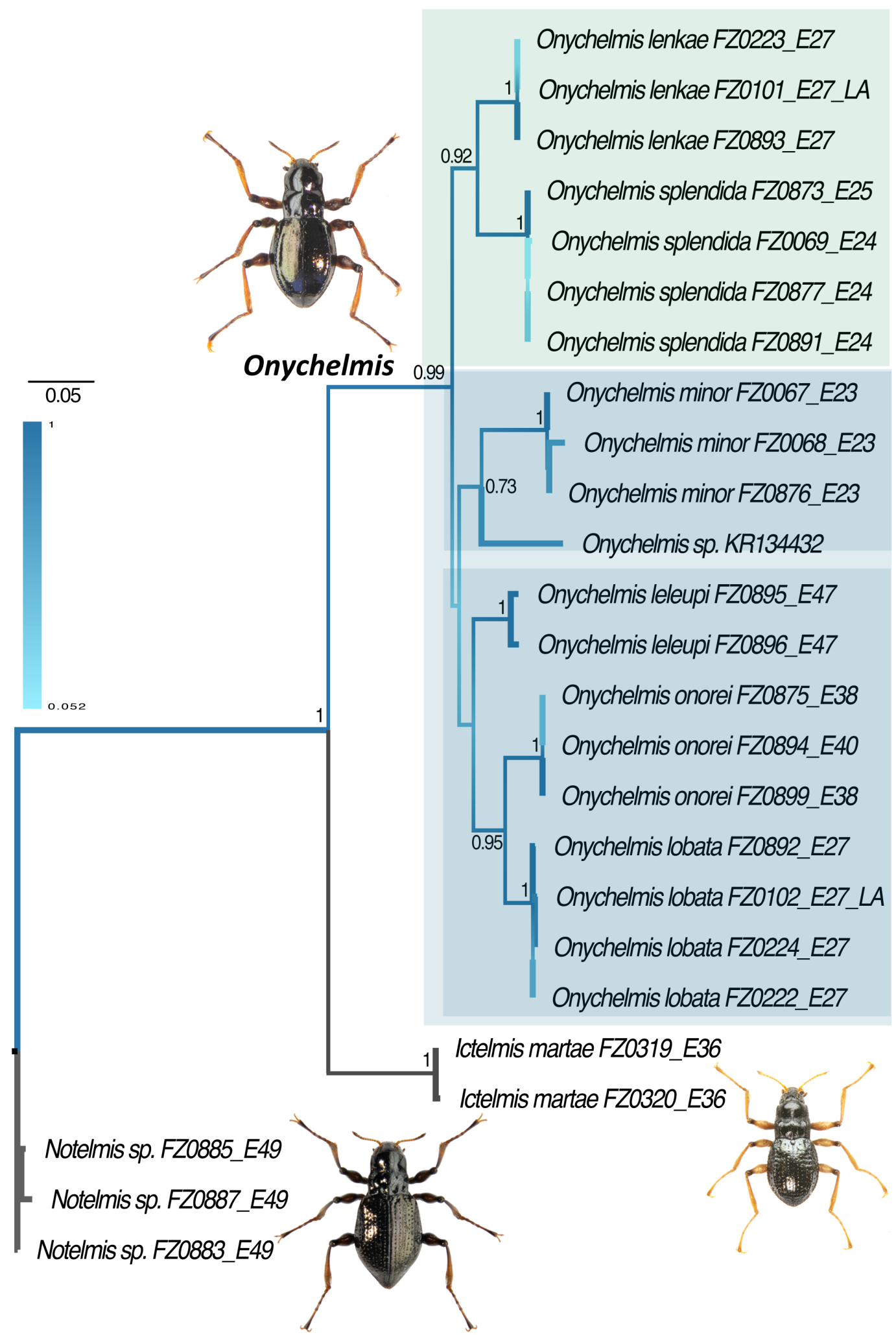

Fig. 1. Maximum likelihood tree obtained with MEGA X for the species of Onychelmis Hinton, 1941. Numbers above branches $=$ Bootstrap support; scale $=$ number of changes. 


\title{
Taxonomy
}

\author{
Class Insecta Linnaeus, 1758 \\ Order Coleoptera Linnaeus, 1758 \\ Suborder Polyphaga Emery, 1886 \\ Superfamily Byrrhoidea Latreille, 1804 \\ Family Elmidae Curtis, 1830
}

Genus Onychelmis Hinton, 1941

Onychelmis Hinton, 1941: 66 (type species: Elmis longicollis Sharp, 1882).

\section{Differential diagnosis}

The genus Onychelmis is characterized as follows: 1) minute, obovate body with glabrous surface; 2) club-like femora; 3) pronotum shiny, without well-developed microreticulation, with deep and complete transverse depression at apical half; 4) pronotum without well-developed sublateral carinae; 5) elytra with sublateral carina on sixth interval or absent; 6) each tarsal claw with basal and subbasal tooth; 7) aedeagus without parameres; 8) ovipositor with short, noncylindrical styli.

\section{Redescription}

\section{Male}

Body. Obovate, $1.01-1.66 \mathrm{~mm}$ long, $0.52-0.81 \mathrm{~mm}$ wide; dorsum convex. Surface shiny with sparse, light yellowish setae. Hairy or scale-like tomentum distributed on following areas: genae, sides of prosternum, mesoventrite, metaventrite and abdomen, epipleura, and medial and lateral portions on bases of femora.

CoLOuR. Head, pronotum and elytra black; venter, mouthparts, prosternum, coxae, trochanters, femora (except for black apices), tibiae, tarsi, metaventrite and abdomen pale brown to dark brown with reddish tinge; basal segments of antennae and tarsal claws pale brown.

HEAD. Narrower than pronotum, retractile, rounded, dorsally shiny. Labrum wider than long, anterolateral angles broadly arcuate with numerous golden, recumbent hair-like setae. Clypeus shorter and wider than labrum, about 3.5 times as wide as long, anterior margin slightly concave, anterolateral angles rounded. Frontoclypeal suture visible. Mandible short, moderately broad, symmetrical; apex curved with three obtuse teeth, molar part with pores. Prostheca large, entirely membranous. Maxilla with cardo and stipes moderately short. Maxillary palp 4-segmented, segments 1-3 short and wide, terminal segment almost twice as long as segments 1-3 combined. Galea elongate, as wide as maxillary palp. Lacinia about twice as wide as galea, longer than wide, subrectangular. Apex and inner side with dense, long, curved setae. Labium with submentum broad, subpentagonal; mentum transverse, as wide as submentum, very short; prementum elongate, anterior half widened, margin densely setigerous. Labial palp 3-segmented, first segment short and wide; second segment more than twice as long as first, distally widened; third segment suboval, equally wide as segments $1-2$, about twice as long as second segment. Antennae filiform, 11-segmented; pedicel about twice as long as scape, remaining segments about 4 times as long as scape and pedicel combined, segments 3-10 subrectangular, subequal in length; terminal segment longest, suboval, with pointed apex. Eyes well developed, hemispherical.

Thorax. Pronotum subparallel, widest behind middle; surface shiny, with narrow reticulation along basal margin and posterolateral angles; sublateral carinae never well-developed (in several species, e.g., $O$. whiteheadi and $O$. leleupi, with a very fine raised line in basal $1 / 6$ or $1 / 8$ ); disc convex, divided by a broad, deep transverse impression before middle; two prescutellar foveae separated by a raised line extending from base to apical discal half, connecting both halves and merging into them; anterior margin 
arcuate; posterior margin bisinuate; sides of pronotum convex before and after transverse constriction; lateral margins narrowly rimmed; posterolateral angles orthogonal; anterolateral angles slightly produced. Hypomeron finely microreticulate, widest in middle. Prosternum moderately long in front of procoxae, with anterior margin concave; sides raised around procoxae, forming carinae, not reaching anterior margin, prosternal process long, moderately broad and with posterior margin broadly rounded. Mesoventrite coarse, short and wide, with deep triangular groove for reception of prosternal process; posterior margin around mesocoxae raised. Metaventrite slightly wider than long, shiny with setigerous punctures; disc convex with medial, triangular depression in posterior half; discrimen in basal $2 / 3$; with one prebasal fovea with setal tufts on each side of metaventrite (Fig. 5; foveae or depression indistinct in a few species, e.g., O. onorei sp. nov. and $O$. minor sp. nov.). Elytra convex, widest in anterior $2 / 3$; sides strongly declivous; surface shiny, with dense tiny punctures; elytral margin narrowly rimmed; humeri indistinctly to broadly produced; epipleuron tapering posteriorly. Prominent sublateral carina on sixth interval reaching $4 / 5$ of elytron length present or absent. Elytra with ten more or less visible rows of punctures, impressed coarsely and deeply to completely absent. Scutellum subovate, flat. Legs moderately long; femora clavate, markedly widened in middle; tibiae longest, apically with cleaning fringe. Tarsi 5-segmented, first four segments each with one fine pale, recumbent seta, fifth segment slightly shorter than remaining segments combined; claws with a large subbasal and smaller basal teeth.

AвDOMEN. With 5 ventrites. First ventrite with basal margin broadly rounded; fifth ventrite longest, apically setose. Aedeagus elongate; parameres absent; phallobase parallel-sided.

\section{Female}

Externally similar to male, except metaventrite without distinct medial, triangular depression in posterior half and without two prebasal foveae, fifth ventrite is more elongate (Fig. 4B) and extension of femoral tomentum is usually greater. Ovipositor with short, noncylindrical stylus.

\section{Distribution}

Known from Central and South America; presence of Onychelmis specimens is reported in at least eight countries: Colombia, Costa Rica, Ecuador, Guatemala, Honduras, Panama, Peru and Venezuela (Fig. 12B).

\section{Key to the species of Onychelmis}

1. Carina on sixth elytral interval absent

O. splendida sp. nov.

- Carina on sixth elytral interval present 2

2. Body size larger than $1.30 \mathrm{~mm}$

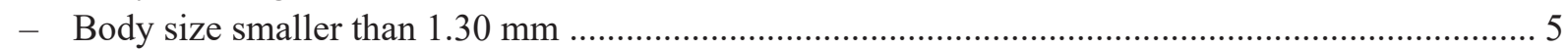

3. Males with profemoral tomentum reaching around half(Fig. 6A) .............. O. leleupi Delève, 1968

- Males with profemoral tomentum at base (Fig. 6C, H) .

4. Smaller size (CL: $1.35-1.37 \mathrm{~mm}$ ); apex of penis broadly rounded with medial projection (Fig. 8C)

O. lobata sp. nov.

- Larger size (CL: 1.65-1.66 mm); apex of penis trilobate (Fig. 7A) O. whiteheadi Spangler \& Santiago, 1991

5. Humeri produced (Fig. 3C, E) 6

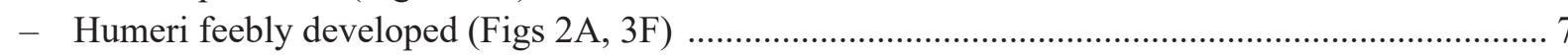


6. Elytral punctures absent; penis lanceolate (Fig. 10A)

O. lenkae sp. nov.

- Elytral punctures shallowly impressed; penis with rounded, medially projected apex (Fig. 9A) ......

O. onorei sp. nov.

7. Smaller size (CL: 1.01-1.07 mm); elytral punctures reduced; males with mesofemoral tomentum reaching below apex (Fig. 6E); apex of penis rounded with medial projection (Fig. 10C)

O. minor sp. nov.

- Larger size (CL: $1.27 \mathrm{~mm}$ ); elytral punctures moderately impressed; males with mesofemoral tomentum reaching around middle (Fig. 6D); penis lanceolate (Fig. 7C)

O. longicollis (Sharp, 1882)

Onychelmis longicollis (Sharp, 1882)

Figs 2A-B, 6D, 7C-D, 12B

Elmis longicollis Sharp, 1882: 138.

Onychelmis longicollis - Hinton 1941: 67, figs 7-8. — Spangler \& Santiago 1991: 497, figs 3-4. González-Córdoba et al. 2016: 11, figs 5a-b, 7c-b.

\section{Differential diagnosis}

Onychelmis longicollis can be distinguished from all species of the genus by the combination of the following characters: 1) smaller size (CL: $1.27 \mathrm{~mm}$ ); 2) tomentum on profemora reaching behind middle, on mesofemora to around middle (Fig. 6D); 3) humeri feebly developed; 4) prominent carina on sixth elytral interval present; 5) elytral punctures moderately impressed; 6) shape of aedeagus lanceolate (Fig. 7C-D).

\section{Material examined}

\section{Holotype}

PANAMA - đ’; "Elmis longicollis Type D.S. V.de Chiriqui 4-6000ft. Panama. Champion // ô // Type [red disc] // V. de Chiriqui 4000-6000 ft. Champion. // B.C.A. Col. I. 2. Elmis longicollis Sharp.”; NHM.

\section{Redescription}

Male (holotype)

Body. Obovate (Fig. 2A-B); length $1.27 \mathrm{~mm}$; width $0.60 \mathrm{~mm}$; dorsum convex, glabrous. Body with sparse, light yellowish setae. Hairy or scale-like tomentum distributed on following areas: genae, sides of prosternum, mesoventrite, metaventrite and abdomen, epipleura, and medial and lateral portions of bases of femora.

Colour. Head, pronotum and elytra black; venter dark brown with reddish tinge; trochanters, tibiae and tarsi brown; first two segments of antennae and tarsal claws pale brown.

HEAD. Partly retractable into prothorax. Antennae with only 2 segments remaining; pedicel about twice as long as scape. Labrum with anterior margin almost straight; anterolateral angles broadly arcuate with numerous golden, recumbent hair-like setae; clypeus shorter and wider than labrum, about 3.5 times as wide as long; anterior margin slightly concave, anterolateral angles rounded; frontoclypeal suture almost straight. Eyes well developed, HW: $0.29 \mathrm{~mm}$, ID: $0.14 \mathrm{~mm}$, suboval in lateral view, protruding from head outline in dorsal view, circumocular surface raised. Frons convex between eyes.

Thorax. Pronotum widest behind middle, PW: $0.41 \mathrm{~mm}$, PL: $0.43 \mathrm{~mm}$; surface shiny, with narrow reticulation along basal margin and posterolateral angles, with dense tiny punctures; sublateral carinae 
absent, fine raised line indistinct; disc convex, divided by a broad, deep transverse impression before middle; two prescutellar foveae separated by a raised line extending from base to apical discal half, connecting both halves and merging into them; anterior margin arcuate; posterior margin bisinuate; sides of pronotum convex before and after transverse constriction; lateral margins narrowly rimmed; posterolateral angles orthogonal; anterolateral angles slightly produced. Hypomeron finely microreticulate, widest in middle. Prosternum moderately long in front of procoxae, with anterior margin concave; sides raised around procoxae, forming carinae, not reaching anterior margin, prosternal process long, moderately broad and with posterior margin broadly rounded. Mesoventrite coarse, short and wide, with deep triangular groove for reception of prosternal process; posterior margin around mesocoxae raised. Metaventrite slightly wider than long, rugose, more or less shiny with setigerous punctures; disc convex

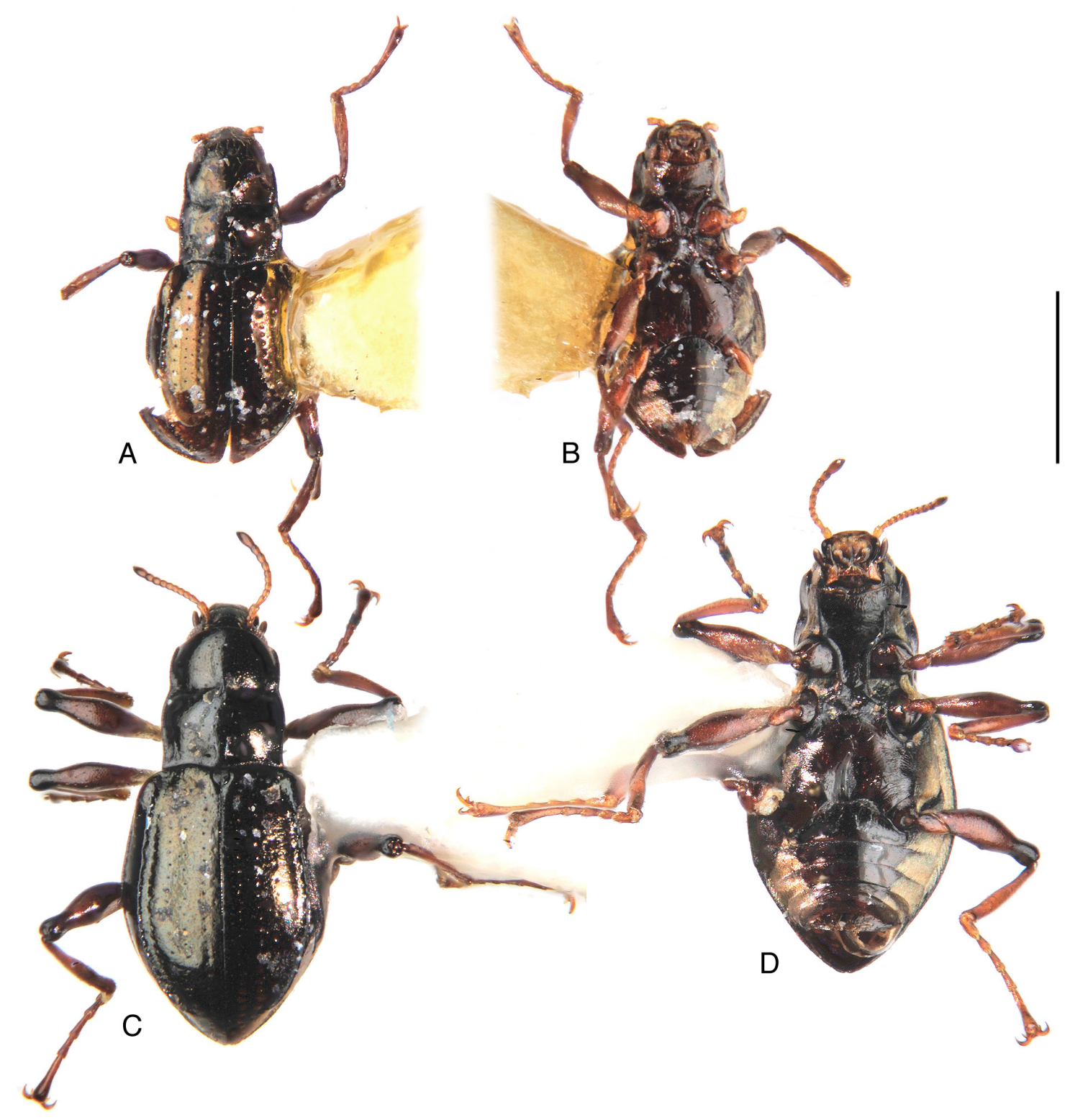

Fig. 2. Habitus of Onychelmis spp. A-B. O. longicollis (Sharp, 1882), holotype, §ิ (NHM). A. Dorsal view. B. Ventral view. C-D. O. whiteheadi Spangler \& Santiago, 1991, holotype, $\precsim$ (NMNH). C. Dorsal view. D. Ventral view. Scale bar $=0.5 \mathrm{~mm}$. 
with deep, medial, triangular depression in posterior half; discrimen in basal $2 / 3$; with one prebasal fovea on each side of metaventrite. Elytra (EL: $0.85 \mathrm{~mm}$, EW: $0.60 \mathrm{~mm}$ ) convex, widest in anterior $2 / 3$; sides strongly declivous; surface shiny, with dense tiny punctures; elytral margin narrowly rimmed; humeri feebly developed; epipleuron tapering posteriorly. Prominent carina on sixth interval well developed, reaching $4 / 5$ of elytron. Elytra with ten rows of small punctures, moderately impressed, separated by $1-2$ times puncture diameter, diminishing toward lateral margins and elytral apex. Scutellum subovate, flat. Legs moderately long; femora clavate; tibiae longest, apically with cleaning fringes. Tarsi 5-segmented, first four segments each with one fine pale, recumbent seta, fifth segment slightly shorter than remaining segments combined; claws with a large subbasal and smaller basal teeth.

AвDomen. With 5 ventrites. First ventrite with basal margin broadly rounded; fifth ventrite longest, apically setose, with posterior margin broadly arcuate. Aedeagus (Fig. 7C-D) elongate. Penis without fibula; corona in apical half; in ventral view convex, from apical half tapering toward broad rounded apex; in lateral view slender, evenly narrowed from base to slightly curved apex. Parameres absent. Phallobase about 1.5 times as long as penis, subparallel, in ventral view straight, slightly curved in lateral view.

\section{Female}

Unknown.

\section{Distribution}

The species is reported from three countries (Fig. 12B), Colombia (González-Córdoba et al. 2016), Nicaragua (Shepard pers. com.) and Panama (Sharp 1882). However, the holotype, first illustrated herein, differs from the non-type O. longicollis from Colombia depicted in Spangler \& Santiago (1991) and later followed by González-Córdoba et al. (2016), and it is possible that they in fact represent different species, and therefore the correct distribution of $O$. longicollis needs to be reviewed.

\section{Remarks}

As stated by Sharp (1882), the type specimen is in poor condition and some characters like tibial fringes, which Hinton (1941) incorrectly interpreted as plastron, are difficult to properly observe. Antennal segments 3-11, the left hind leg and the tarsus of the left mid leg are missing, the left elytron is broken, and the left foreleg is glued to the mounting point.

Onychelmis whiteheadi Spangler \& Santiago, 1991

Figs 2C-D, 6H, 7A-B, 12B

Onychelmis whiteheadi Spangler \& Santiago, 1991: 495, figs 1-2.

\section{Differential diagnosis}

Onychelmis whiteheadi can be distinguished from other species of the genus by the combination of the following characters: 1) larger size (CL: $1.65-1.66 \mathrm{~mm}) ; 2$ ) pro- and mesofemora with tomentum at base (Fig. 6H); 3) humeri produced; 4) prominent carina on sixth interval present; 5) elytral punctures shallowly impressed; 6) apex of aedeagus trilobate (Fig. 7A-B).

\section{Material examined}

Holotype

COLOMBIA • đ̃; "COLOMBIA: [CUND.]: Río Cachéta near Bogota, 26 Feb 1984, Maria T. Szauer // [red] HOLOTYPE Onychelmis whiteheadi Spangler \& Santiago."; NMNH. 


\section{Paratype}

COLOMBIA • 1 đ̊; "COLOMBIA: [CUND.]: Río Cachéta near Bogota, 26 Feb 1984, Maria T. Szauer // [blue] PARATYPE Onychelmis whiteheadi Spangler \& Santiago.”; NMNH.

\section{Redescription}

\section{Male}

Body. Obovate, black (Fig. 2C-D); length $1.65-1.66 \mathrm{~mm}$; width $0.79-0.81 \mathrm{~mm}$; dorsum convex, glabrous, with sparse, light yellowish setae. Hairy or scale-like tomentum distributed on following areas: genae, sides of prosternum, mesoventrite, metaventrite and abdomen, epipleura, and medial and lateral portions on bases of femora.

Colour. Head, pronotum and elytra black; venter dark brown to black; coxae, femora and tarsi dark brown with reddish tinge; trochanters and tibiae brown; basal segments of antennae and tarsal claws pale brown.

HEAD. Partly retractable into prothorax, dorsally shiny. Antennae filiform, 11-segmented; pedicel about twice as long as scape; remaining segments about 4 times as long as scape and pedicel combined, segments 3-10 subrectangular, subequal in length; terminal segment longest, suboval, with pointed apex. Labrum with anterior margin very slightly emarginate medially; anterolateral angles broadly arcuate with numerous golden, recumbent hair-like setae; clypeus shorter and wider than labrum, about 3.5 times as wide as long, anterior margin slightly concave, anterolateral angles rounded; frontoclypeal suture almost straight. Eyes well developed, HW: 0.31-0.32 mm, ID: 0.15-0.16 mm, suboval in lateral view, protruding from head outline in dorsal view, circumocular surface raised. Frons convex between eyes.

Thorax. Pronotum widest behind middle, PW: $0.47-0.48 \mathrm{~mm}$, PL: $0.51-0.54 \mathrm{~mm}$; surface shiny, with narrow reticulation along basal margin and posterolateral angles, with dense tiny punctures; sublateral carinae never well-developed, but a short, very fine raised line in basal $1 / 6$ present; disc convex, divided by a broad, deep transverse impression before middle; two prescutellar foveae separated by a raised line extending from base to apical discal half, connecting both halves and merging into them; anterior margin arcuate; posterior margin bisinuate; sides of pronotum convex before and after transverse constriction; lateral margins narrowly rimmed; posterolateral angles orthogonal; anterolateral angles slightly produced. Hypomeron finely microreticulate, widest in middle. Prosternum moderately long in front of procoxae, with anterior margin concave; sides raised around procoxae, forming carinae, not reaching anterior margin, prosternal process long, moderately broad and with posterior margin broadly rounded. Mesoventrite coarse, short and wide, with deep triangular groove for reception of prosternal process; posterior margin around mesocoxae raised. Metaventrite slightly wider than long, wrinkled, more or less shiny with setigerous punctures; disc convex with deep, medial, triangular depression in posterior half; discrimen in basal 2/3; in males with one prebasal fovea on each side. Elytra (EL: 0.12-0.15 mm, EW: $0.79-0.81 \mathrm{~mm}$ ) convex, widest in anterior $2 / 3$; sides strongly declivous; surface shiny, with dense tiny punctures; elytral margin narrowly rimmed; humeri protruding from outline; epipleuron tapering posteriorly. Prominent carina on sixth interval in $4 / 5$ of elytron. Elytra with ten rows of small, shallowly impressed punctures, separated by $2-4$ times puncture diameter, diminishing toward lateral margins and elytral apex. Scutellum subovate, flat. Legs moderately long; femora clavate; tibiae longest. Protibiae with anterior cleaning fringe on apical $1 / 3$; mesotibiae with two cleaning fringes - anterior on apical $1 / 5$ and posterior on apical $1 \frac{1}{3}$; metatibiae with posterior cleaning fringe on apical $1 / 3$. Tarsi 5 -segmented, first four segments each with one fine pale, recumbent seta, fifth segment slightly shorter than remaining segments combined; claws with a large subbasal and smaller basal teeth. 
AвDomen. With 5 ventrites. First ventrite with basal margin broadly rounded, fifth ventrite longest, apically setose, with posterior margin broadly arcuate. Aedeagus (Fig. 7A-B) elongate. Penis without fibula; corona below apex, well developed; in ventral view concave, from apical half widening toward laterally projected, apically nearly acute sides, apical margin medially with wide arcuate projection; in lateral view thick, evenly narrowed from base to curved apex, with apical sides pointing backwards. Parameres absent. Phallobase about 1.5 times as long as penis, subparallel, distal portion markedly narrowed, in ventral view straight, curved in lateral view.

\section{Female}

Unknown.

\section{Distribution}

Known only from the type locality in Cundinamarca, Colombia (Fig. 12B).

Onychelmis leleupi Delève, 1968

Figs 3A, 6A, 8A-B, 10E, 11A, 12A-B

Onychelmis leleupi Delève, 1968: 217, figs 4-11.

Onychelmis leleupi - González-Córdoba et al. 2016: 10, figs 5c-d, 6b-c.

\section{Differential diagnosis}

Onychelmis leleupi can be distinguished from all species of the genus by the combination of the following characters: 1) larger size (CL: 1.44-1.51 mm); 2) pro- and mesofemora with tomentum reaching around middle (Fig. 6A); 3) humeri produced; 4) prominent carina on sixth interval present; 5) elytral punctures shallowly impressed; 6) apex of aedeagus trilobate (Fig. 8A-B).

\section{Material examined}

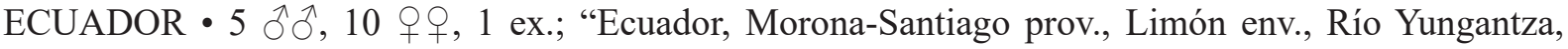
$02^{\circ} 59^{\prime} 49.3^{\prime \prime} \mathrm{S}, 78^{\circ} 29^{\prime} 18.9^{\prime \prime} \mathrm{W}, 1522 \mathrm{~m}$ a.s.1., 27. 8. 2013, stream ca. $3 \mathrm{~m}$ wide, fast flowing, partly shaded, with boulders, stones, gravel, Čiampor \& Čiamporová-Zat'ovičová lgt.”; PUCE/CCB.

\section{Redescription}

\section{Male}

BoDy. Obovate, black (Fig. 3A); length 1.44-1.51 mm; width 0.66-0.68 mm; dorsum convex, glabrous with sparse, light yellowish setae. Hairy or scale-like tomentum distributed on following areas: genae, sides of prosternum, mesoventrite, metaventrite and abdomen, epipleura, and medial and lateral portions on bases of femora.

CoLour. Head, pronotum and elytra black; venter dark brown to black with reddish tinge; coxae, femora and tarsi dark brown with reddish tinge; trochanters and tibiae brown; basal segments of antennae and tarsal claws pale brown.

HEAD. Partly retractable into prothorax, dorsally shiny. Antennae filiform, 11-segmented; pedicel about twice as long as scape; remaining segments about 4 times as long as scape and pedicel combined; segments 3-10 subrectangular, subequal in length; terminal segment longest, suboval, with pointed apex. Labrum with anterior margin very slightly emarginate medially; anterolateral angles broadly arcuate with numerous golden, recumbent hair-like setae; clypeus shorter and wider than labrum, about 3.5 times as wide as long, anterior margin slightly concave, anterolateral angles rounded; frontoclypeal 


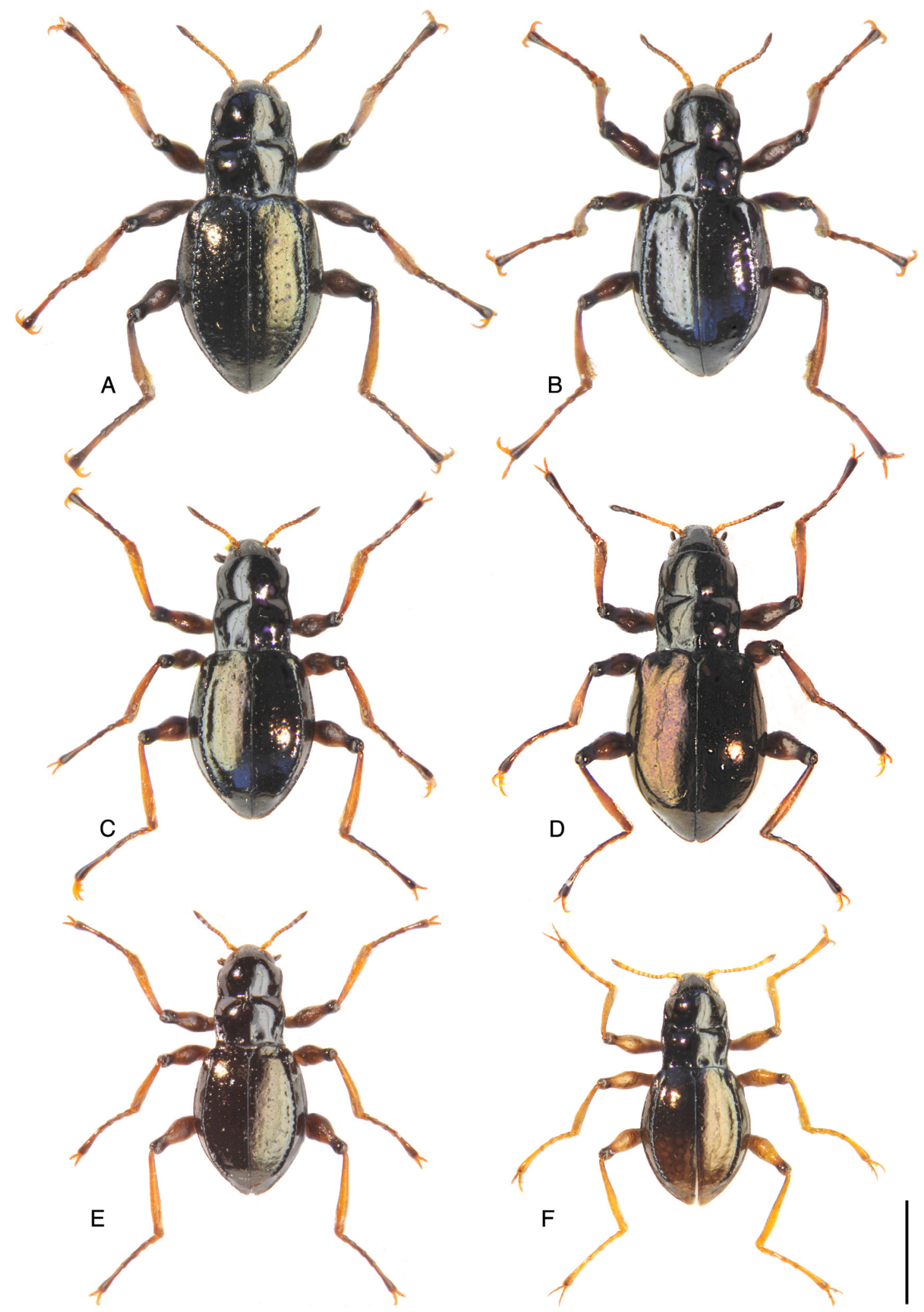

Fig. 3. Habitus of Onychelmis spp. A. O. leleupi Delève, 1968, ô (PUCE). B. O. lobata sp. nov.,

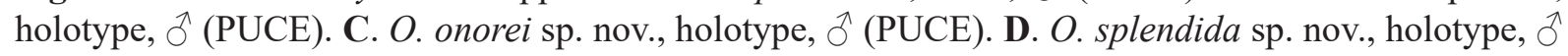

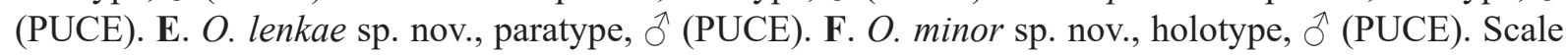
bar $=0.5 \mathrm{~mm}$. 
suture almost straight. Eyes well developed, HW: 0.29-0.31 mm, ID: 0.13-0.15 mm, suboval in lateral view, protruding from head outline in dorsal view, circumocular surface raised. Frons convex between eyes.

ThORax. Pronotum widest behind middle, PW: $0.41-0.43 \mathrm{~mm}$, PL: $0.66-0.68 \mathrm{~mm}$; surface shiny, with microreticulation only along basal margin and posterolateral angles, with dense tiny punctures; sublateral carinae never well-developed, but a short, very fine raised line in basal $1 \frac{1}{6}$ present; disc convex, divided by a broad, deep transverse impression before middle; two prescutellar foveae separated by a raised line extending from base to apical discal half, connecting both halves and merging into them; anterior margin arcuate; posterior margin bisinuate; sides of pronotum convex before and after transverse constriction; lateral margins narrowly rimmed; posterolateral angles orthogonal; anterolateral angles slightly produced. Hypomeron finely microreticulate, widest in middle. Prosternum moderately long in front of procoxae, with anterior margin concave; sides raised around procoxae, forming carinae, not reaching anterior margin, prosternal process long, moderately broad and with posterior margin broadly rounded. Mesoventrite coarse, short and wide, with deep triangular groove for reception of prosternal process; posterior margin around mesocoxae raised. Metaventrite slightly wider than long, wrinkled, more or less shiny; disc convex with deep, medial, triangular depression in posterior half; discrimen in basal 2/3; with one prebasal fovea on each side. Elytra (EL: 0.96-0.99 mm, EW: 0.68-0.69 mm) convex, widest in anterior $2 / 3$; sides strongly declivous; surface shiny, with dense tiny punctures; elytral margin narrowly rimmed; humeri protruding from outline; epipleuron tapering posteriorly. Prominent carina on sixth interval reaching $4 / 5$ of elytron. Elytra with ten rows of small, shallowly impressed punctures, separated by 2-4 times puncture diameter, diminishing toward lateral margins and elytral apex. Scutellum subovate, flat. Legs moderately long; femora clavate; tibiae longest. Protibiae with anterior cleaning fringe on apical $1 / 3$; mesotibiae with two cleaning fringes - anterior on apical $1 / 5$ and posterior on apical $1 / 3$; metatibiae with posterior cleaning fringe on apical $1 / 3$. Tarsi 5 -segmented, first four segments each with one fine pale, recumbent seta, fifth segment slightly shorter than remaining segments combined; claws with a large subbasal and smaller basal teeth.

AbDomen. With 5 ventrites. First ventrite with basal margin broadly rounded; fifth ventrite longest, apically setose, with posterior margin broadly arcuate. Aedeagus (Fig. 8A-B) elongate. Penis without fibula; corona at apex, well developed; in ventral view parallel-sided, apically extended, apex rounded with medial projection; in lateral view slender, evenly narrowed from base to slightly curved apex. Parameres absent. Phallobase slightly longer than penis, parallel-sided, in ventral view straight, curved in lateral view.

\section{Female}

Externally similar to male, except metaventrite without distinct medial, triangular depression in posterior half and without two prebasal foveae, fifth ventrite more elongate and extension of femoral tomentum slightly greater. Ovipositor (Fig. 10E) with very short, laterally curved stylus; preterminal segment long, narrow, widened at base, well sclerotized, about 10 times as long as stylus, with sparse curved blunt and acuminate spines; basal segment membranous, about as long as preterminal and distal segments combined, baculus curved, well sclerotized.

\section{Biology}

This species inhabits fast-flowing, mountain or submontane streams (Fig. 11A).

\section{Distribution}

Known from Ecuador, Colombia and Peru (Delève 1968; Shepard \& Chaboo 2015; González-Córdoba et al. 2016) (Fig. 12A-B). 


\author{
Onychelmis lobata sp. nov. \\ urn:1sid:zoobank.org:act:C0675943-40CF-4147-BC50-D35A7F0CF840 \\ Figs 3B, 4, 6C, 8C-D, 11B, 11F, 12A-B
}

\title{
Differential diagnosis
}

Onychelmis lobata sp. nov. can be distinguished from all species of the genus by the combination of the following characters: 1) moderate size (CL: $1.35-1.37 \mathrm{~mm}$ ); 2) pro- and mesofemora with tomentum at base in males, and around middle in females (Fig. 6C); 3) humeri produced; 4) prominent carina on sixth interval present; 5) elytral punctures shallowly impressed; 6) apex of aedeagus broadly rounded, medially with arcuate projection (Fig. 8C-D).

\section{Etymology}

The species is named after its larva (to be described in a separate study), which possesses distinct cuticular lobes.

\section{Material examined}

\section{Holotype}

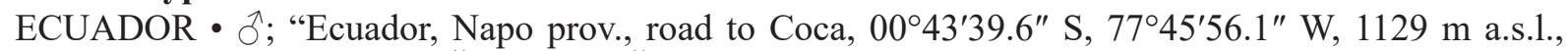
17. 8. 2013, small waterfall, Čiampor \& Čiamporová-Zatovičová lgt.”; PUCE.

\section{Paratypes}

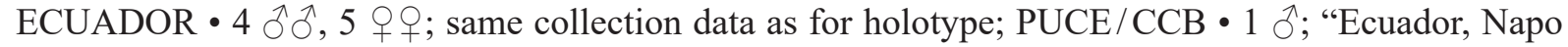
prov., road to Coca, Sumaco env., 0043'29.0" S, 77²4'01.4" W, 1109 m a.s.1., 17. 8. 2013, confluence of two larger streams, with gravel, stones, boulders, Čiampor \& Čiamporová-Zat'ovičová lgt.";

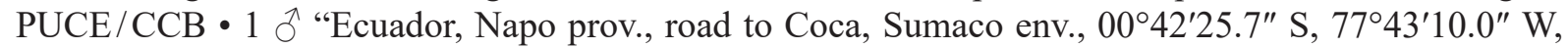
$1138 \mathrm{~m}$ a.s.1., 17. 8. 2013, stream ca. 2-3 m wide, fast flowing, with boulders, stones, gravel, submerged wood, Čiampor \& Čiamporová-Zat'ovičová lgt”; PUCE/CCB.

\section{Other material}

ECUADOR • 1 ô, 5 qq, 1 larva; same collection data as for holotype; CCB.

\section{Description}

\section{Male}

BoDy. Obovate, black (Fig. 3B); length $1.35-1.37 \mathrm{~mm}$; width 0.62-0.68 mm; dorsum convex, glabrous with sparse, light yellowish-brown setae. Hairy or scale-like tomentum distributed on following areas: genae, sides of prosternum, mesoventrite, metaventrite and abdomen, epipleura, and medial and lateral portions on bases of femora.

Colour. Head, pronotum and elytra black; venter, mouthparts, prosternum, coxae, tibiae, tarsi, metaventrite and abdomen brown to dark brown with reddish tinge; trochanters pale brown to reddish brown; basal segments of antennae and tarsal claws pale brown.

HEAD. Partly retractable into prothorax, dorsally shiny. Antennae filiform, 11-segmented; pedicel about twice as long as scape; remaining segments about 4 times as long as scape and pedicel combined; segments 3-10 subrectangular, subequal in length; terminal segment longest, suboval, with pointed apex. Labrum with anterior margin very slightly emarginate medially; anterolateral angles broadly arcuate with numerous golden, recumbent hair-like setae; clypeus shorter and wider than labrum, about 3.5 times as wide as long, anterior margin slightly concave, anterolateral angles rounded; frontoclypeal suture almost straight. Eyes well developed, HW: 0.27-0.30 mm, ID: 0.12-0.15 mm, suboval in lateral view, protruding from head outline in dorsal view, circumocular surface raised. Frons between eyes convex. 
Thorax. Pronotum widest behind middle, PW: 0.41-0.42 mm, PL: 0.47-0.48 mm; surface shiny, with narrow reticulation along basal margin and posterolateral angles, with dense tiny punctures; sublateral carinae never well-developed, fine raised sublateral lines indistinct; disc convex, divided by a broad, deep transverse impression before middle; prescutellar foveae separated by a raised line extending from base to middle, connecting pre- and postimpression portions and merging into them; anterior margin arcuate; posterior margin bisinuate; sides of pronotum convex before and after transverse constriction; lateral margins narrowly rimmed; posterolateral angles orthogonal; anterolateral angles slightly produced. Hypomeron finely microreticulate, widest in middle. Prosternum moderately long in front of procoxae, with anterior margin concave; sides raised around procoxae, forming carinae, not reaching anterior margin, prosternal process long, moderately broad, with posterior margin broadly rounded. Mesoventrite coarse, short and wide, with deep triangular groove for reception of prosternal process; posterior margin around mesocoxae raised. Metaventrite slightly wider than long, shiny with setigerous punctures; disc convex with deep, medial, triangular depression in posterior half; discrimen in basal $2 / 3$, very thin, indistinct; with prebasal fovea on each side of metaventrite. Elytra (EL: 0.88-0.91 mm, EW: $0.62-0.68 \mathrm{~mm}$ ) convex, widest in anterior $2 / 3$, sides strongly declivous; surface shiny, with dense tiny punctures; elytral margin narrowly rimmed; humeri protruding from outline; epipleuron tapering posteriorly. Prominent carina on sixth interval reaching $4 / 5$ of elytron. Elytra with ten rows of small, shallowly impressed punctures, separated by $2-4$ times puncture diameter, diminishing toward lateral margins and elytral apex. Scutellum subovate, flat. Legs moderately long; femora clavate; tibiae longest. Protibiae with anterior cleaning fringe on apical $1 / 3$; mesotibiae with two cleaning fringes - anterior on apical $1 / 5$ and posterior on apical $1 / 3$; metatibiae with posterior cleaning fringe on apical $1 / 3$. Tarsi 5 -segmented, first four segments each with one fine pale, recumbent seta, fifth segment slightly shorter than remaining segments combined; claws with a large subbasal and smaller basal teeth.

AвDOMEn. With 5 ventrites. First ventrite with basal margin broadly rounded; fifth ventrite longest, apically setose, with posterior margin broadly arcuate (Fig. 4A). Aedeagus (Fig. 8C-D) elongate. Penis without fibula; corona in apical half; in ventral view subparallel, apically widened, apex rounded with medial protuberance; in lateral view curved, evenly narrowed from base to apex. Parameres absent. Phallobase about as long as penis, parallel-sided, in ventral view straight, slightly curved in lateral view.

\section{Female}

Externally similar to male, except metaventrite without distinct medial, triangular depression in posterior half and without two prebasal foveae, fifth ventrite more elongate (Fig. 4B) and extension of femoral tomentum greater.
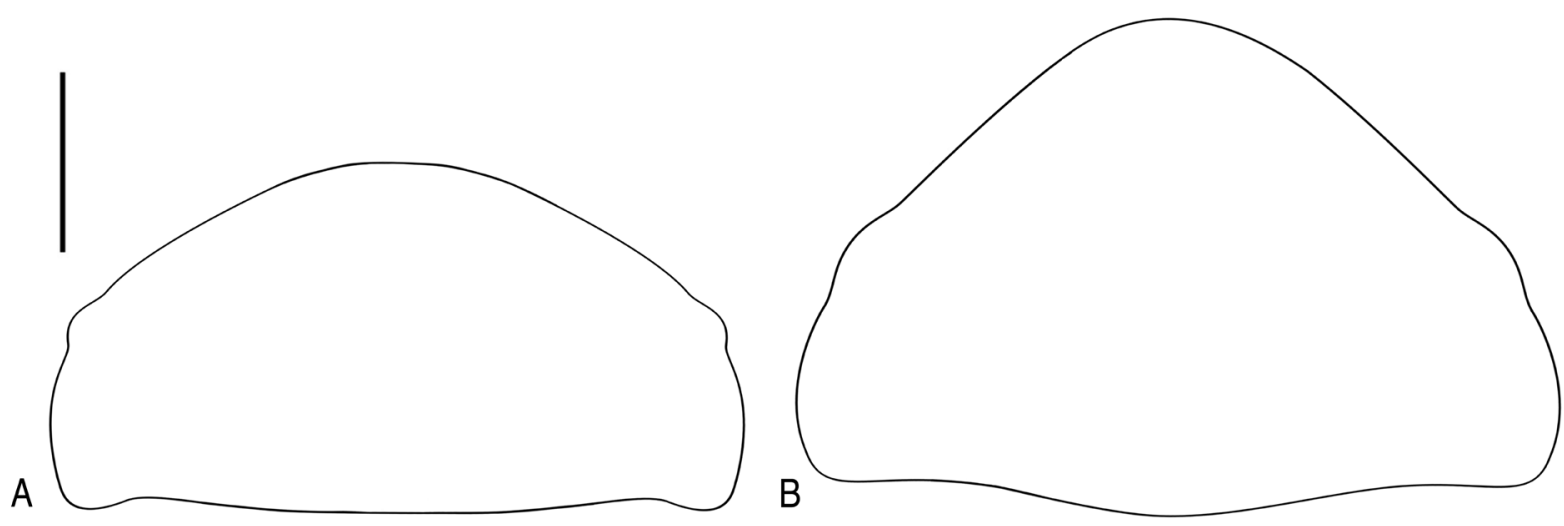

Fig. 4. Fifth ventrite of $O$. lobata sp. nov. A. Male. B. Female. Scale bar $=0.1 \mathrm{~mm}$. 


\section{Biology}

Collected from small stream directly below waterfall surrounded by remnants of primary forest, with water flowing between larger stones (Fig. 11B).

\section{Distribution}

Known from three localities in Napo Province (Figs 11B, F, 12A-B).

Onychelmis onorei $\mathrm{sp}$. nov.

urn:1sid:zoobank.org:act:2D3F3034-4FD5-4761-BC6B-693EBBDAB6EB

Figs 3C, 6F, 9A-B, 11C-D, 12A-B

\section{Differential diagnosis}

Onychelmis onorei sp. nov. can be distinguished from all species of the genus by the combination of the following characters: 1) smaller size (CL: $1.25-1.26 \mathrm{~mm}$ ); 2) tomentum on profemora reaching behind middle, on mesofemora to around middle (Fig. 6F); 3) humeri produced; 4) prominent carina on sixth interval present; 5) elytral punctures shallowly impressed; 6) apex of aedeagus subtriangular (Fig. 9A-B).

\section{Etymology}

This species is dedicated to Prof. Giovanni Onore from the Pontificial Catholic University of Ecuador (Quito), entomologist, enthusiastic nature conservationist and a very good friend.

\section{Material examined}

\section{Holotype}

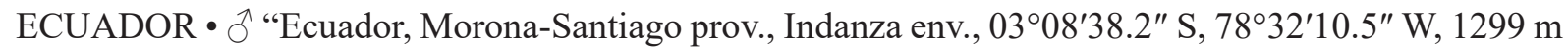
a.s.1., 24. 8. 2013, stream ca. $5 \mathrm{~m}$ wide, with gravel, boulders, leaf debris, submerged wood, Čiampor \& Čiamporová-Zat'ovičová lgt.”; PUCE.

\section{Paratypes}

ECUADOR • 2 q $q$; same collection data as for holotype; PUCE/CCB 11 ○, 1 q; "Ecuador, MoronaSantiago prov., Santa Rosa de Mamanguy env., Cascada la Encañada, $03^{\circ} 05^{\prime} 14.7^{\prime \prime}$ S, $78^{\circ} 24^{\prime} 36.0^{\prime \prime}$ W, $698 \mathrm{~m}$ a.s.1., 25. 8. 2013, stream ca. 2-3 m wide under waterfall, with clay, gravel, stones, submerged wood, Čiampor \& Čiamporová-Zatovičová lgt.”; PUCE/CCB.

\section{Other material}

ECUADOR $・ 1$ § ; same collection data as for holotype; CCB.

\section{Description}

\section{Male}

BoDy. Obovate, black (Fig. 3C); length $1.25-1.26 \mathrm{~mm}$; width $0.58-0.64 \mathrm{~mm}$; dorsum convex, glabrous with sparse, light yellowish-brown setae. Hairy or scale-like tomentum distributed on following areas: genae, sides of prosternum, mesoventrite, metaventrite and abdomen, epipleura, and medial and lateral portions on bases of femora.

CoLour. Head, pronotum and elytra black; venter dark brown to black with reddish tinge; coxae, femora and tarsi dark brown with reddish tinge; trochanters and tibiae brown; basal segments of antennae and tarsal claws pale brown. 
HEAD. Partly retractable into prothorax, dorsally shiny. Antennae filiform, 11-segmented; pedicel about twice as long as scape; remaining segments about 4 times as long as scape and pedicel combined; segments 3-10 subrectangular, subequal in length; terminal segment longest, suboval, with pointed apex. Labrum with anterior margin almost straight; anterolateral angles broadly arcuate with numerous golden, recumbent hair-like setae; clypeus shorter and wider than labrum, about 3.5 times as wide as long, anterior margin slightly concave, anterolateral angles rounded; frontoclypeal suture almost straight. Eyes well developed, HW: $0.26-0.28 \mathrm{~mm}$, ID: $0.14-0.16 \mathrm{~mm}$, suboval in lateral view, protruding from head outline in dorsal view, circumocular surface raised. Frons between eyes convex.

Thorax. Pronotum widest behind middle, PW: 0.38-0.41 mm, PL: 0.47-0.49 mm; surface shiny, with narrow reticulation along basal margin and posterolateral angles, with dense tiny punctures; sublateral carinae never well-developed, but a short, very fine raised sublateral line in basal $1 / 8$ present; disc convex, divided by a broad, deep transverse impression before middle; prescutellar foveae separated by a raised line extending from base to middle connecting pre- and postimpression portions and merging into them; anterior margin arcuate; posterior margin bisinuate; sides of pronotum convex before and after transverse constriction; lateral margins narrowly rimmed; posterolateral angles orthogonal; anterolateral angles slightly produced. Hypomeron finely microreticulate, widest in middle. Prosternum moderately long in front of procoxae, with anterior margin concave; sides raised around procoxae, forming carinae, not reaching anterior margin, prosternal process long, moderately broad, with posterior margin broadly rounded. Mesoventrite coarse, short and wide, with deep triangular groove for reception of prosternal process; posterior margin around mesocoxae raised. Metaventrite slightly wider than long, shiny with setigerous punctures; disc convex with very shallow to indistinct medial, triangular depression in posterior half; discrimen in basal $2 / 3$, very thin, indistinct; prebasal foveae absent. Elytra (EL: 0.77-0.81 $\mathrm{mm}$, EW: $0.58-0.64 \mathrm{~mm}$ ) convex, widest in anterior $2 / 3$; sides strongly declivous; surface shiny, with dense tiny punctures; elytral margin narrowly rimmed; humeri protruding from outline; epipleuron tapering posteriorly. Prominent carina on sixth interval reaching $4 / 5$ of elytron. Elytra with ten rows of small, shallowly impressed punctures, separated by a 2-4 times puncture diameter, diminishing toward lateral margins and elytral apex or absent. Scutellum subovate, flat. Legs moderately long; femora clavate; tibiae longest. Protibiae with anterior cleaning fringe on apical $1 / 3$; mesotibiae with two cleaning fringes - anterior on apical $1 / 5$ and posterior on apical $1 / 3$; metatibiae with posterior cleaning fringe on apical $1 / 3$. Tarsi 5 -segmented, first four segments each with one fine pale, recumbent seta, fifth segment slightly shorter than remaining segments combined; claws with a large subbasal and smaller basal teeth.

AвDOMEn. With 5 ventrites. First ventrite with basal margin broadly rounded, fifth ventrite longest, apically setose with posterior margin broadly arcuate. Aedeagus (Fig. 9A-B) elongate. Penis without fibula; corona in apical half; in ventral view parallel-sided, apically extended, apex subtriangular; in lateral view straight, ventrally narrowed from base to apex. Parameres absent. Phallobase slightly longer than penis, parallel-sided, in ventral view straight, slightly curved in lateral view.

\section{Female}

Externally similar to male, except fifth ventrite more elongate and extension of femoral tomentum slightly greater.

\section{Biology}

Collected from small shaded stream in forest with cascades, riffles, substrate with large boulders, stones, gravel and sand (Fig. 11C).

\section{Distribution}

Known only from two localities in Morona-Santiago Province (Figs 11C-D, 12A-B). 
Onychelmis splendida sp. nov.

urn:1sid:zoobank.org:act:56128631-3C7F-4D7E-941E-DDA1DC318912

Figs 3D, 5B, 6G, 9C-D, 11B, 11F, 12A-B

\section{Differential diagnosis}

Onychelmis splendida sp. nov. can be distinguished from all species of the genus by the combination of the following characters: 1) moderate size (CL: $1.37-1.40 \mathrm{~mm}$ ); 2) pro- and mesofemora with tomentum reaching to around middle in males, and behind middle in females (Fig. 6G); 3) humeri produced; 4) prominent carina on sixth interval absent; 5) elytral punctures absent; 6) shape of aedeagus lanceolate (Fig. 9C-D).

\section{Etymology}

The specific epithet splendida is from the Latin 'splendidus' ('shiny') referring to the glabrous, shiny elytra.

\section{Material examined}

\section{Holotype}

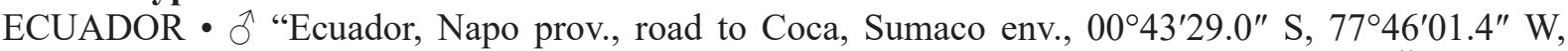
1109 m a.s.1., 17. 8. 2013, confluence of two larger streams, with gravel, stones, boulders, Čiampor \& Čiamporová-Zat'ovičová lgt."; PUCE.
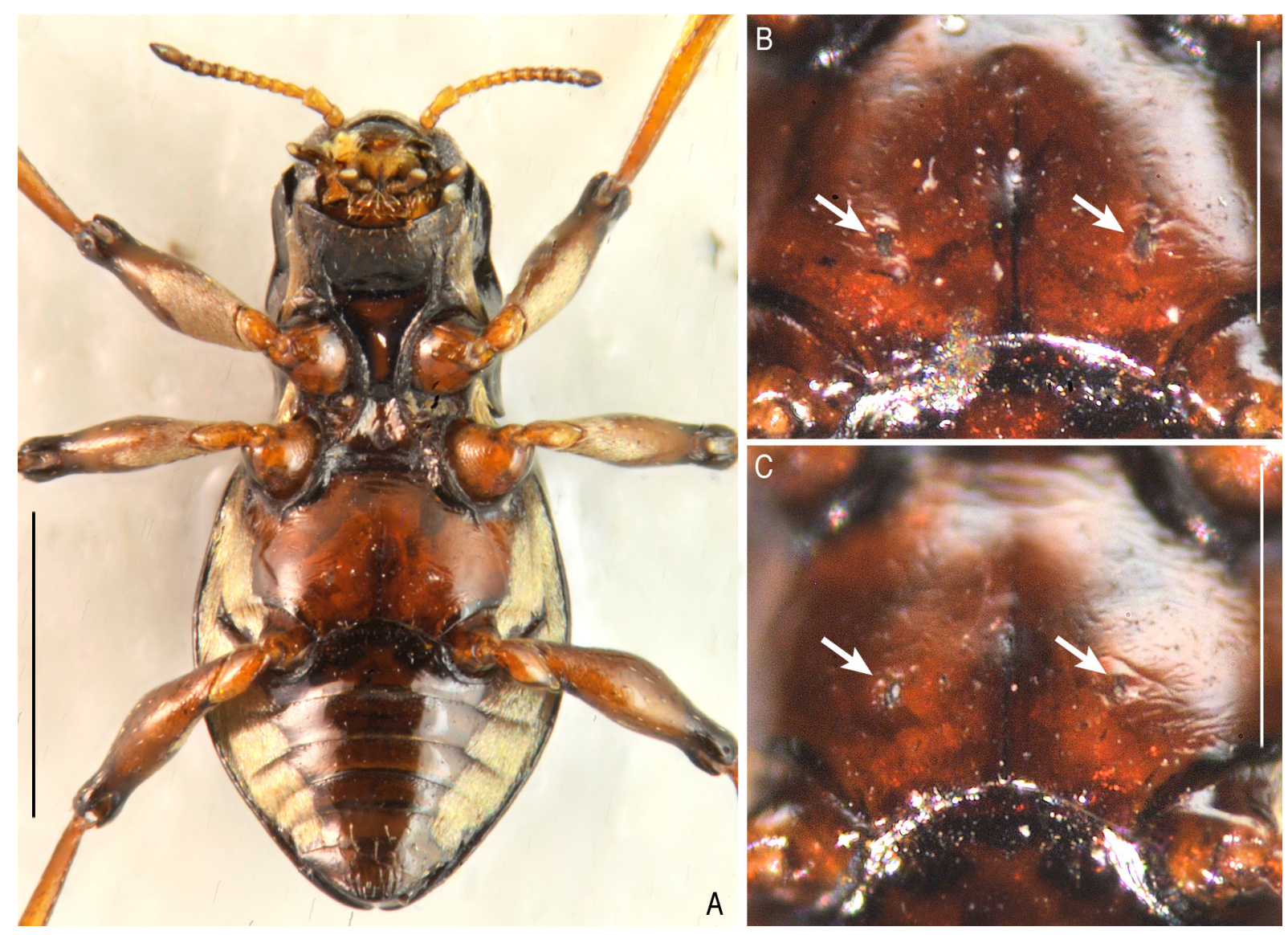

Fig. 5. Venter and metaventrites of male Onychelmis spp. A, C. O. lenkae sp. nov., paratype, ô (PUCE). B. O. splendida sp. nov., paratype, $\widehat{\curvearrowright}$ (PUCE). Arrows show setal tufts. Scale bars: A $=0.5 \mathrm{~mm}$; B-C = $0.3 \mathrm{~mm}$. 


\section{Paratypes}

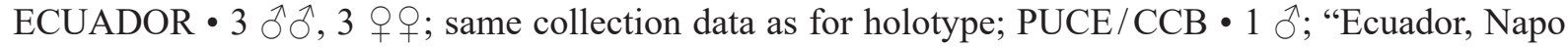

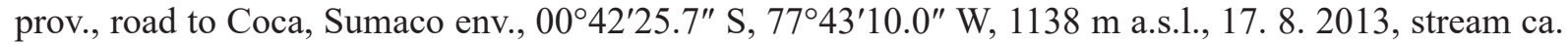
2-3 m wide, fast flowing, with boulders, stones, gravel, submerged wood, Čiampor \& ČiamporováZat'ovičová lgt."; PUCE/CCB • 1 Ô, 3 우; "Ecuador, Napo prov., road to Coca, 0043'39.6" S, 77²5'56.1" W, 1129 m a.s.1., 17. 8. 2013, small waterfall, Čiampor \& Čiamporová-Zatovičová lgt."; $\mathrm{PUCE} / \mathrm{CCB}$.

\section{Other material}

ECUADOR • 1 ک̊; same collection data as for holotype; CCB.

\section{Description}

\section{Male}

Body (Fig. 3D). Obovate, black dorsally, brown ventrally; length $1.37-1.40 \mathrm{~mm}$; width $0.64-0.68$ $\mathrm{mm}$; dorsum convex, glabrous with sparse, light yellowish-brown setae. Hairy or scale-like tomentum distributed on following areas: genae, sides of prosternum, mesoventrite, metaventrite and abdomen, epipleura, and medial and lateral portions on bases of femora.

Colour. Head, pronotum and elytra black; venter dark brown to black with reddish tinge; coxae, femora and tarsi dark brown with reddish tinge; trochanters and tibiae brown; basal segments of antennae and tarsal claws pale brown.

HEAD. Partly retractable into prothorax, dorsally shiny. Antennae filiform, 11-segmented; pedicel about twice as long as scape; remaining segments about 4 times as long as scape and pedicel combined; segments 3-10 subrectangular, subequal in length; terminal segment longest, suboval, with pointed apex. Labrum with anterior margin very slightly emarginate medially; anterolateral angles broadly
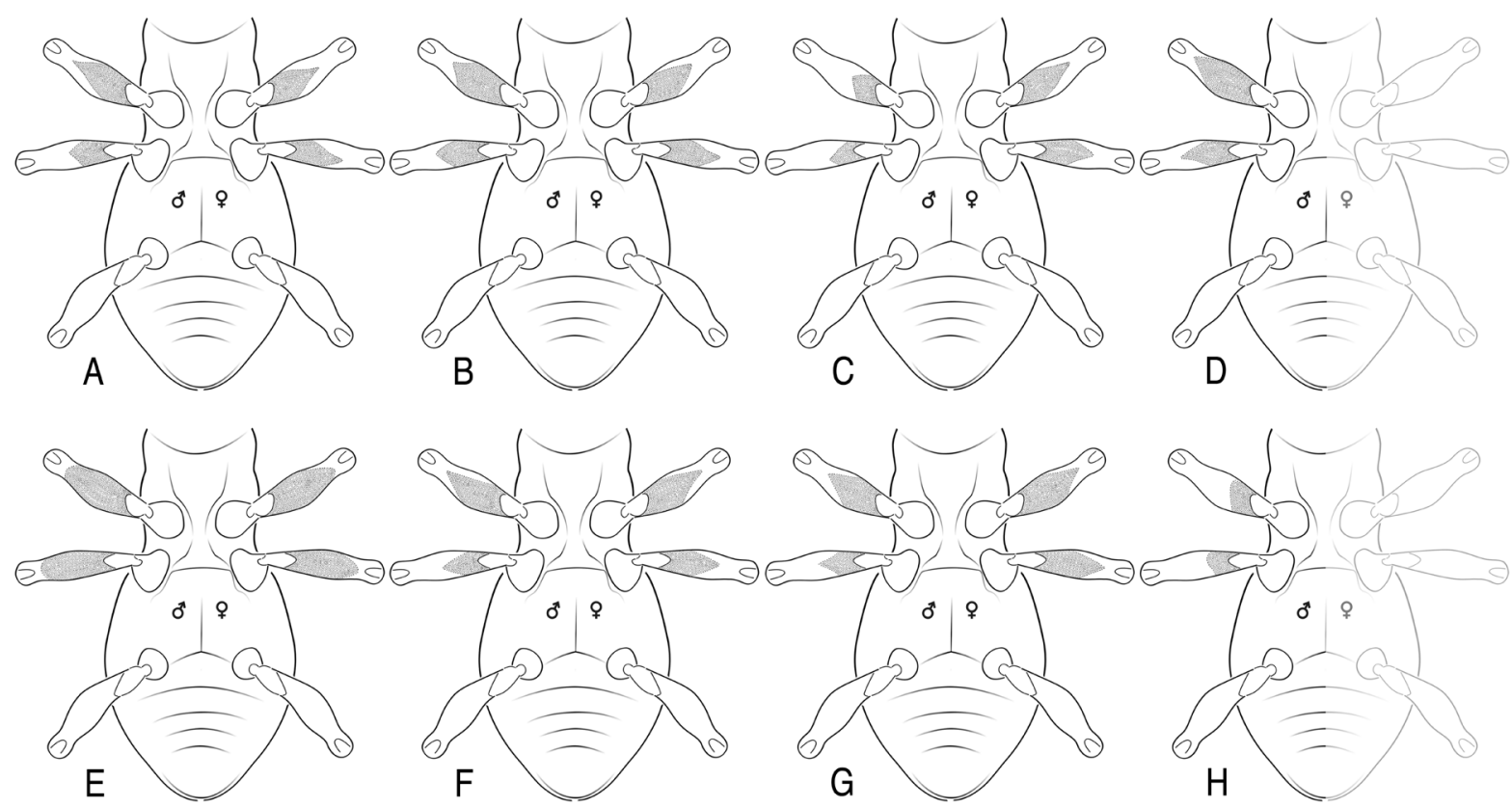

Fig. 6. Tomentum on pro- and mesofemora of Onychelmis spp. A. O. leleupi Delève, 1968. B. O. lenkae sp. nov. C. O. lobata sp. nov. D. O. longicollis (Sharp, 1882). E. O. minor sp. nov. F. O. onorei sp. nov. G. O. splendida sp. nov. H. O. whiteheadi Spangler \& Santiago, 1991. Drawings are schematic, bodies are divided to identical halves: left $=$ male, right $=$ female (note: females unknown for $\mathrm{D}$ and $\mathrm{H}$ ). 
arcuate with numerous golden, recumbent hair-like setae; clypeus shorter and wider than labrum, about 3.5 times as wide as long, anterior margin slightly concave, anterolateral angles rounded; frontoclypeal suture almost straight. Eyes well developed, HW: 0.30-0.31 mm, ID: $0.17-0.18 \mathrm{~mm}$, suboval in lateral view, protruding from head outline in dorsal view, circumocular surface raised. Frons between eyes convex.

Thorax. Pronotum widest behind middle, PW: 0.41-0.43 mm, PL: 0.47-0.49 mm; surface shiny, with narrow reticulation along basal margin and posterolateral angles, with dense tiny punctures; sublateral carinae absent, fine raised line indistinct; disc convex, divided by a broad, deep transverse impression before middle; two prescutellar foveae separated by a raised line extending from base to apical discal half, connecting pronotal halves and merging into them; anterior margin arcuate; posterior margin bisinuate; sides of pronotum convex before and after transverse constriction; lateral margins narrowly rimmed; posterolateral angles orthogonal; anterolateral angles slightly produced. Hypomeron finely microreticulate, widest in middle. Prosternum moderately long in front of procoxae, with anterior margin concave; sides raised around procoxae, forming carinae, not reaching anterior margin, prosternal process long, moderately broad, with posterior margin broadly rounded. Mesoventrite coarse, short and wide, with deep triangular groove for reception of prosternal process; posterior margin around mesocoxae raised. Metaventrite slightly wider than long, shiny; disc convex with very shallow to indistinct, medial, triangular depression in posterior half; discrimen in basal $2 / 3$, very thin, almost indistinct; with one prebasal fovea on each side of metaventrite (Fig. 5B). Elytra (EL: 0.89-0.92 mm, EW: 0.64-0.68 mm) convex, widest in anterior $2 / 3$; sides strongly declivous; surface shiny, with dense tiny punctures; elytral margin narrowly rimmed; humeri protruding from outline; epipleuron tapering posteriorly; sublateral carina absent; strial punctures absent (in few specimens a partial striation is present). Scutellum subovate, flat. Legs moderately long; femora clavate; tibiae longest. Protibiae with anterior cleaning fringe on apical $1 / 3$; mesotibiae with two cleaning fringes - anterior on apical $1 / 5$ and posterior on apical $1 / 3$; metatibiae with posterior cleaning fringe on apical $1 / 3$. Tarsi 5 -segmented, first four segments each with one fine pale, recumbent seta, fifth segment slightly shorter than remaining segments combined; claws with a large subbasal and smaller basal teeth.

AвDOMEN. With 5 ventrites. First ventrite with basal margin broadly rounded, fifth ventrite longest, apically setose, with posterior margin broadly arcuate. Aedeagus (Fig. 9C-D) elongate. Penis elongate, without fibula; corona in basal half; in ventral view concave with rounded apex; in lateral view evenly narrowed from base to curved apex. Parameres absent. Phallobase almost 2 times as long as penis, parallel-sided, in ventral view straight, curved in lateral view.

\section{Female}

Externally similar to male, except metaventrite without prebasal foveae, fifth ventrite more elongate and extension of femoral tomentum greater.

\section{Biology}

Collected from stream ca $7 \mathrm{~m}$ wide in deforested area with riffles and pools, close to the confluence with a larger stream, substrate composed of boulders, stones and gravel (Fig. 11F).

\section{Distribution}

Known from three localities in Napo Province (Figs 11B, F, 12A-B). 

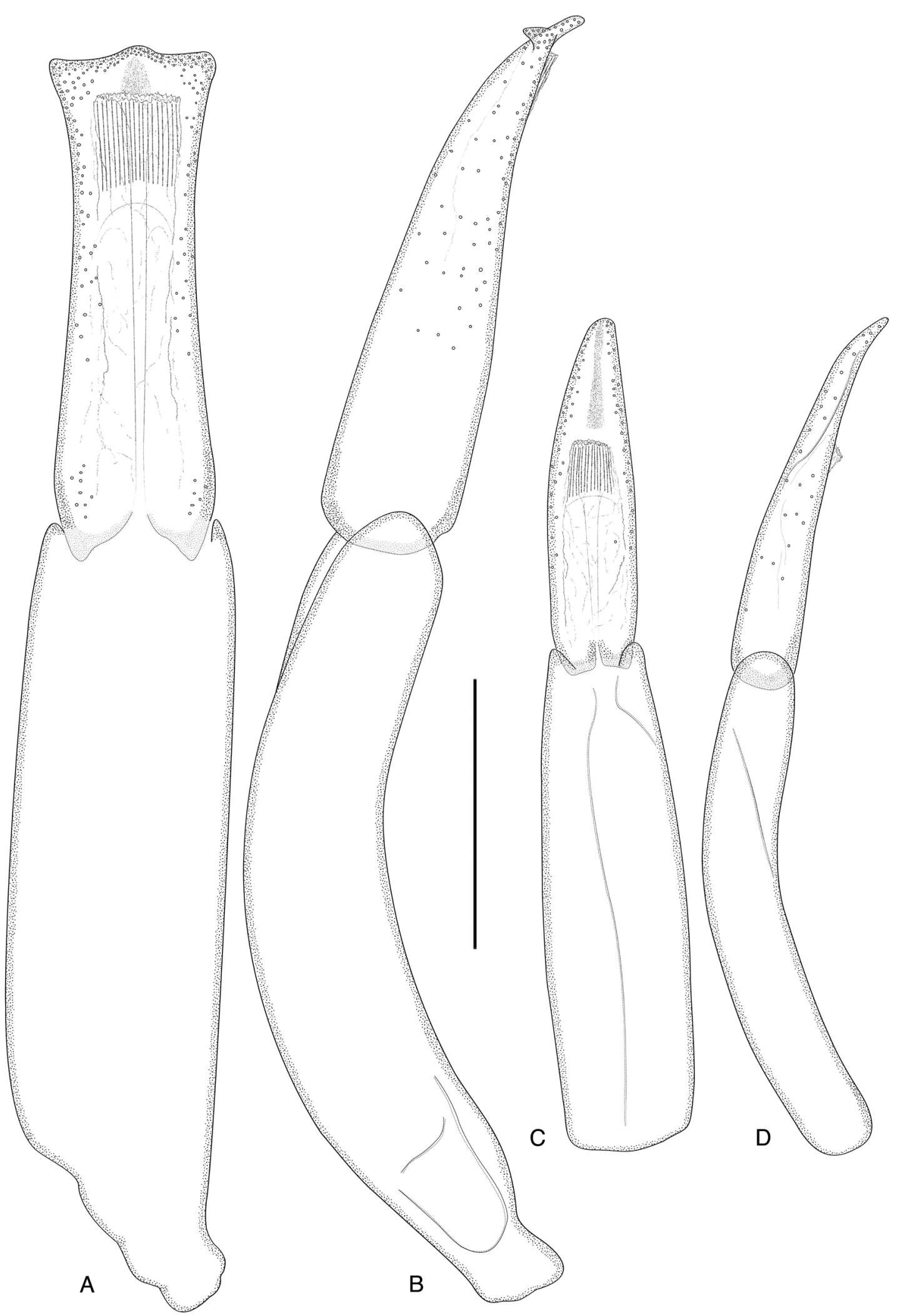

Fig. 7. Aedeagi of Onychelmis spp. A. O. whiteheadi Spangler \& Santiago, 1991, ventral view. B. O. whiteheadi, lateral view. C. O. longicollis (Sharp, 1882), ventral view. D. O. longicollis, lateral view. Scale bar $=0.1 \mathrm{~mm}$. 

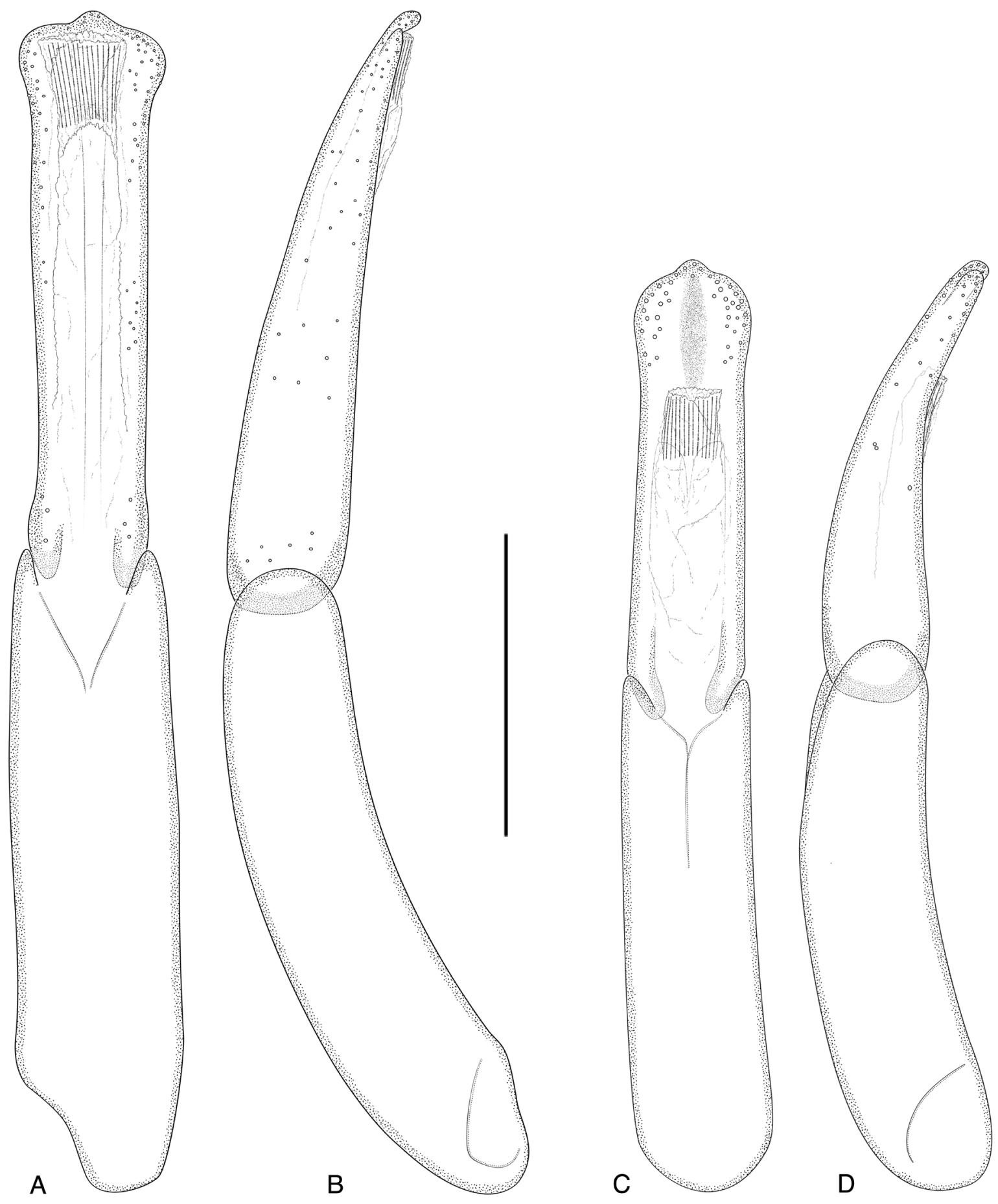

Fig. 8. Aedeagi of Onychelmis spp. A. O. leleupi Delève, 1968, ventral view. B. O. leleupi, lateral view. C. O. lobata sp. nov., ventral view. D. O. lobata sp. nov., lateral view. Scale bar $=0.1 \mathrm{~mm}$. 

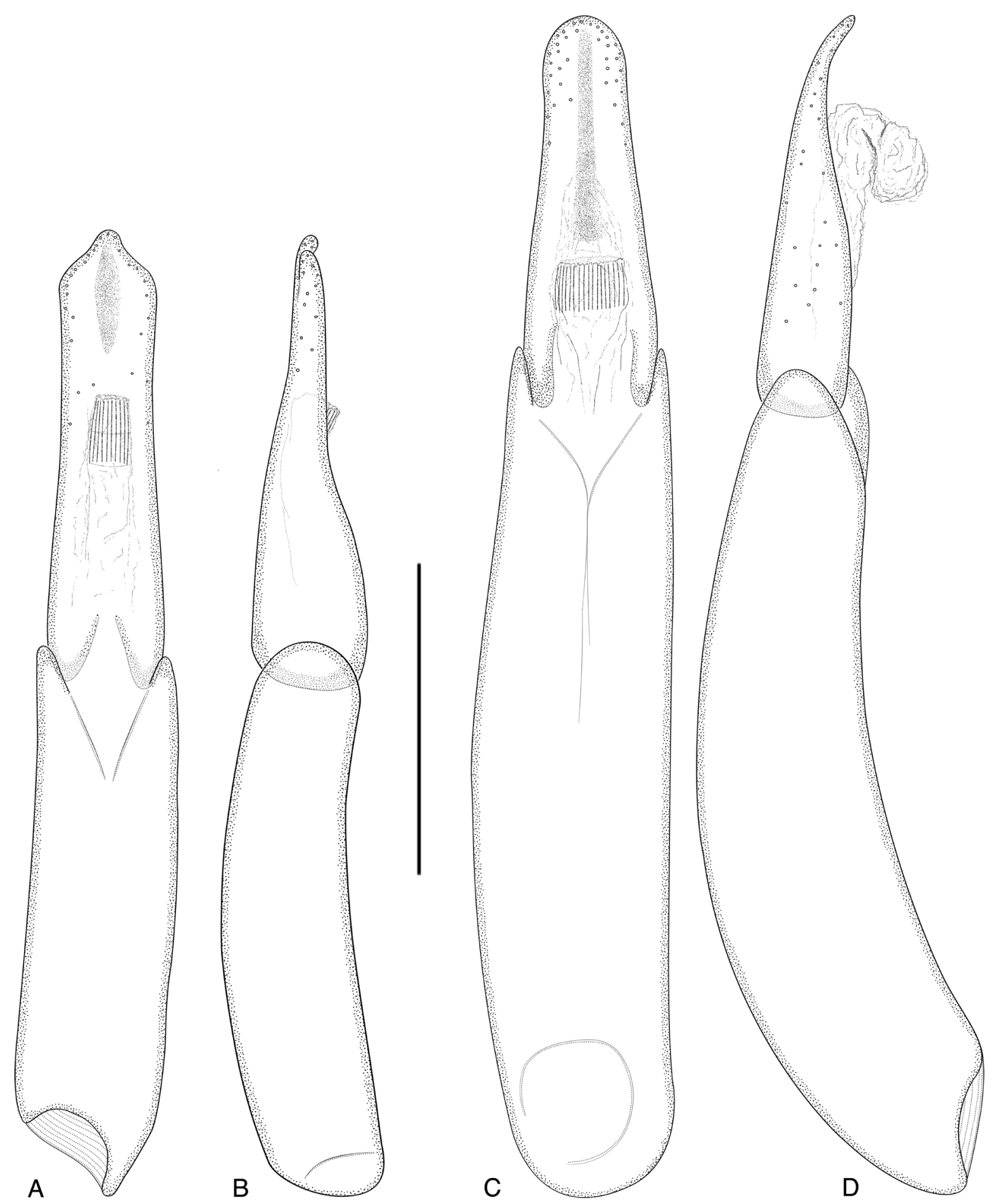

Fig. 9. Aedeagi of Onychelmis spp. A. O. onorei sp. nov., ventral view. B. O. onorei sp. nov., lateral view. C. O. splendida sp. nov., ventral view. D. O. splendida sp. nov., lateral view. Scale bar $=0.1 \mathrm{~mm}$. 

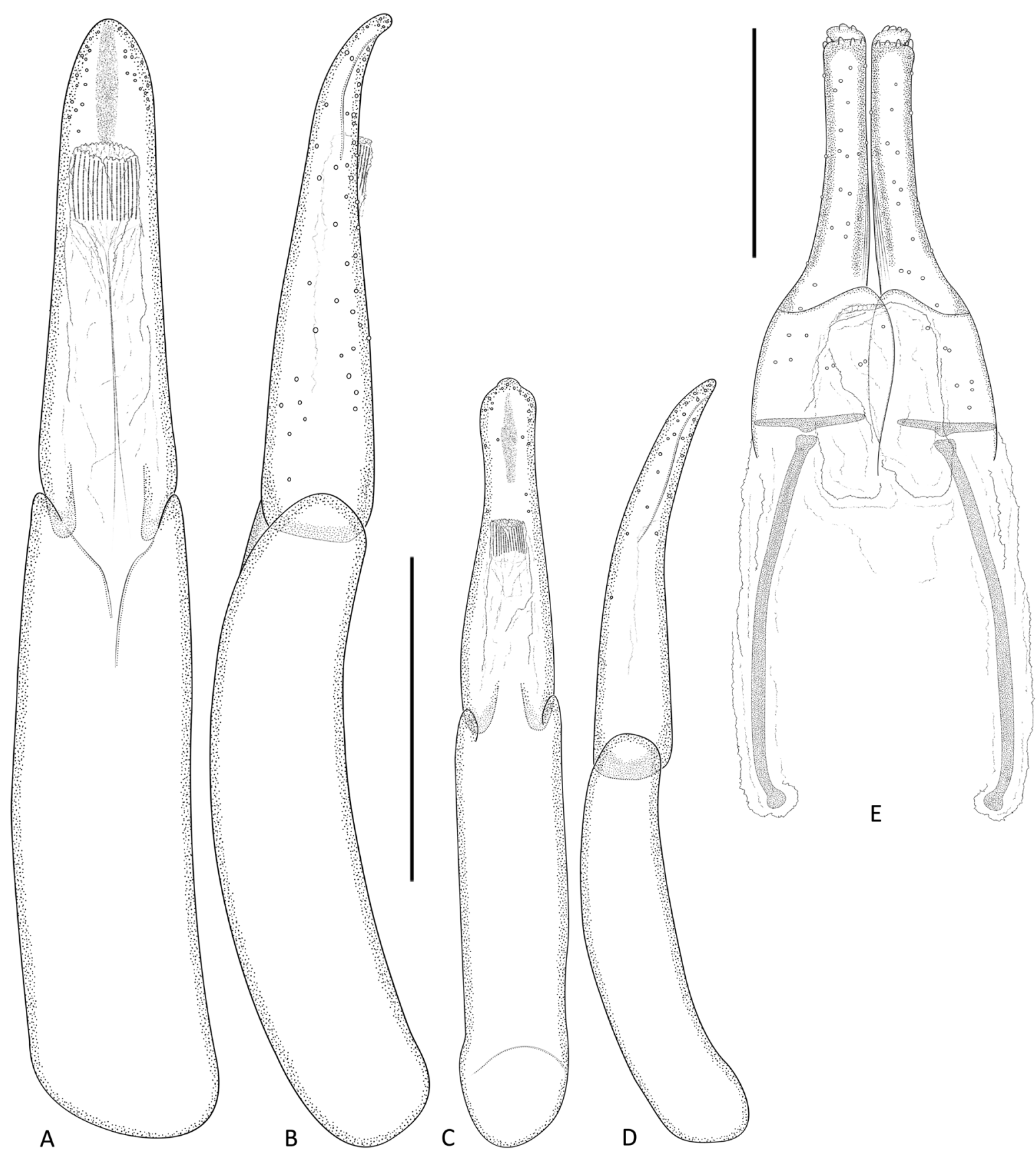

Fig. 10. Aedeagi (A-D) and ovipositor (E) of Onychelmis spp. A. O. lenkae sp. nov., ventral view. B. O. lenkae sp. nov., lateral view. C. O. minor sp. nov., ventral view. D. O. minor sp. nov., lateral view. E. O. leleupi Delève, 1968 , ovipositor, ventral view. Scale bars $=0.1 \mathrm{~mm}$. 


\author{
Onychelmis lenkae sp. nov. \\ urn:Isid:zoobank.org:act:4573D7BA-F92E-4E98-A90B-E49F5AAE79C4 \\ Figs $3 \mathrm{E}, 5 \mathrm{~A}, \mathrm{C}, 6 \mathrm{~B}, 10 \mathrm{~A}-\mathrm{B}, 11 \mathrm{~B}, 12 \mathrm{~A}-\mathrm{B}$
}

\title{
Differential diagnosis
}

Onychelmis lenkae sp. nov. can be distinguished from all species of the genus by the combination of the following characters: 1) smaller size (CL: $1.24-1.28 \mathrm{~mm}$ ); 2) pro- and mesofemora with tomentum reaching to around middle (Fig. 6B); 3) humeri produced; 4) prominent carina on sixth interval present; 5) elytral punctures absent; 6) shape of aedeagus lanceolate (Fig. 10A-B).

\section{Etymology}

This species is named after daughter of ZČZ and FČ, Lenka Čiamporová. She helped a lot during collecting in Ecuador although she was only five at the time.

\section{Material examined}

\section{Holotype}

ECUADOR - O'; "Ecuador, Napo prov., road to Coca, 0043'39.6" S, 77045'56.1" W, $1129 \mathrm{~m}$ a.s.1., 17. 8. 2013, small stream below waterfall, Čiampor \& Čiamporová-Zat'ovičová lgt.”; PUCE.

\section{Paratypes}

ECUADOR $・ 5$ ふぇ, 5 우; same collection data as for holotype; PUCE/CCB.

\section{Other material}

ECUADOR $\bullet 1$ ô, 1 larva; same collection data as for holotype; CCB.

\section{Description}

\section{Male}

Body. Obovate (Fig. 3E), dorsally black, ventrally brown; length $1.24-1.28 \mathrm{~mm}$; width $0.57-0.61 \mathrm{~mm}$; dorsum convex, glabrous with sparse, light yellowish-brown setae. Hairy or scale-like tomentum distributed on following areas: genae, sides of prosternum, mesoventrite, metaventrite and abdomen, epipleura, and medial and lateral portions on bases of femora.

CoLOuR. Head, pronotum and elytra black; venter dark brown to black with reddish tinge; coxae, femora and tarsi dark brown with reddish tinge; trochanters and tibiae brown; basal segments of antennae and tarsal claws pale brown.

HEAD. Partly retractable into prothorax, dorsally shiny. Antennae filiform, 11-segmented; pedicel about twice as long as scape; remaining segments about 4 times as long as scape and pedicel combined; segments 3-10 subrectangular, subequal in length; terminal segment longest, suboval, with pointed apex. Labrum with anterior margin almost straight; anterolateral angles broadly arcuate with numerous golden, recumbent hair-like setae; clypeus shorter and wider than labrum, about 3.5 times as wide as long, anterior margin slightly concave, anterolateral angles rounded; frontoclypeal suture almost straight. Eyes well developed, HW: $0.28-0.30 \mathrm{~mm}$, ID: $0.15-0.16 \mathrm{~mm}$, suboval in lateral view, protruding from head outline in dorsal view, circumocular surface raised. Frons between eyes convex.

ThORAx. Pronotum widest behind middle, PW: $0.38-0.40 \mathrm{~mm}$, PL: $0.46-0.48 \mathrm{~mm}$; surface shiny, with narrow reticulation along basal margin and posterolateral angles, with dense tiny punctures; sublateral carinae never well-developed, but a short, very fine raised line in basal $1 \frac{1}{8}$ present; disc convex, divided by broad, deep transverse impression before middle; two prescutellar foveae separated by a raised line extending from base to discal half, connecting pronotal halves and merging into them; anterior 
margin arcuate; posterior margin bisinuate; sides of pronotum convex before and after transverse constriction; lateral margins narrowly rimmed; posterolateral angles orthogonal; anterolateral angles slightly produced. Hypomeron finely microreticulate, widest in middle. Prosternum moderately long in front of procoxae, with anterior margin concave; sides raised around procoxae, forming carinae, not reaching anterior margin, prosternal process long, moderately broad, with posterior margin broadly rounded. Mesoventrite coarse, short and wide, with deep triangular groove for reception of prosternal process; posterior margin around mesocoxae raised. Metaventrite slightly wider than long, shiny with setigerous punctures; disc convex with moderately deep, medial, triangular depression in posterior half; discrimen in basal $2 / 3$, very thin, almost indistinct; with prebasal fovea on each side (Fig. 5A, C). Elytra (EL: $0.77-0.81 \mathrm{~mm}$, EW: $0.57-0.61 \mathrm{~mm}$ ) convex, widest in anterior $2 / 3$; sides strongly declivous; surface shiny, with tiny punctures; elytral margin narrowly rimmed; humeri protruding from outline; epipleuron tapering posteriorly. Prominent carina on sixth interval reaching $4 / 5$ of elytron; strial punctures absent (in a few specimens a partial striation is present). Scutellum subovate, flat. Legs moderately long; femora clavate; tibiae longest. Protibiae with anterior cleaning fringe on apical $1 / 3$; mesotibiae with two cleaning fringes - anterior on apical $1 / 5$ and posterior on apical $1 / 3$; metatibiae with posterior cleaning fringe on apical $1 / 3$. Tarsi 5 -segmented, first four segments each with one fine pale, recumbent seta, fifth segment slightly shorter than remaining segments combined; claws with a large subbasal and smaller basal teeth.

Aвdomen. With 5 ventrites. First ventrite with basal margin broadly rounded; fifth ventrite longest, apically setose, with posterior margin broadly arcuate. Aedeagus (Fig. 10A-B) elongate. Penis without fibula; corona in apical half; in ventral view subparallel with apex rounded; in lateral view curved, evenly narrowed from base to apex. Parameres absent. Phallobase slightly longer than penis, parallelsided, in ventral view straight, curved in lateral view.

\section{Female}

Externally similar to male, except metaventrite without distinct medial, triangular depression in posterior half and without two prebasal foveae, fifth ventrite more elongate.

\section{Biology}

Collected from small stream directly below waterfall surrounded by remnants of primary forest, with water flowing between larger stones (Fig. 11B).

\section{Distribution}

Known only from the type locality in Napo Province (Figs 11B, 12A-B).

Onychelmis minor sp. nov. urn:1sid:zoobank.org:act:2705174E-0DB2-4D45-90A4-41665435AD62

Figs 3F, 6E, 10C-D, 11E, 12A-B

\section{Differential diagnosis}

Onychelmis minor sp. nov. can be distinguished from all species of the genus by the combination of the following characters: 1) small size (CL: 1.01-1.07 mm); 2) pro- and mesofemora with tomentum reaching below apex (Fig. 6E); 3) humeri not well-developed; 4) prominent carina on sixth interval present; 5) elytral punctures absent; 6) apex of aedeagus rounded with medial projection (Fig. 10C-D).

\section{Etymology}

This species is named for being the smallest sized of all known Onychelmis species. 


\section{Material examined}

\section{Holotype}

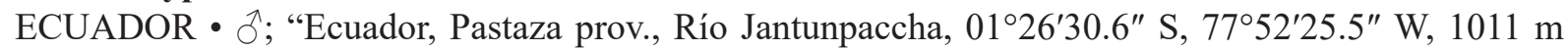
a.s.1., 16. 8. 2013, stream ca. $5 \mathrm{~m}$ wide, slowly flowing, with mud and thin layer of gravel, Čiampor \& Čiamporová-Zat'ovičová lgt."; PUCE.

\section{Paratypes}

ECUADOR $\bullet 2 \widehat{\jmath}, 2$ q $\propto$; same collection data as for holotype; PUCE/CCB.

\section{Other material}

ECUADOR • 1 क ; same collection data as for holotype; CCB.

\section{Description}

Male

Body. Obovate (Fig. 3F); length 1.01-1.07 mm; width 0.52-0.54 mm; dorsum convex, glabrous with sparse, light yellowish-brown setae. Hairy or scale-like tomentum distributed on following areas: genae, sides of prosternum, mesoventrite, metaventrite and abdomen, epipleura, medial and lateral portions on bases of femora.

CoLour. Head, pronotum, elytra, apices of femora, apical half of antennal segments 11 and apical third of tarsi 5 black; venter pale brown to brown with reddish tinge; antennae, coxae, trochanters, femora, tibiae, tarsi and tarsal claws pale brown.

HEAD. Partly retractable into prothorax, dorsally shiny. Antennae filiform, 11-segmented; pedicel about twice as long as scape; remaining segments about 4 times as long as scape and pedicel combined; segments 3-10 subrectangular, subequal in length; terminal segment longest, suboval, with pointed apex. Labrum with anterior margin almost straight; anterolateral angles broadly arcuate with numerous golden, recumbent hair-like setae; clypeus shorter and wider than labrum, about 3.5 times as wide as long, anterior margin slightly concave, anterolateral angles rounded; frontoclypeal suture almost straight. Eyes well developed, HW: $0.25-0.27 \mathrm{~mm}$, ID: $0.15-0.16 \mathrm{~mm}$, suboval in lateral view, protruding from head outline in dorsal view, circumocular surface raised. Frons between eyes convex.

Thorax. Pronotum widest behind middle, PW: $0.34-0.35 \mathrm{~mm}, \mathrm{PL}: 0.37-0.39 \mathrm{~mm}$, surface shiny, with narrow reticulation along basal margin and posterolateral angles, with dense tiny punctures; sublateral carinae never well-developed, fine raised line indistinct; disc convex, divided by broad, deep transverse impression on apical side of middle; two prescutellar foveae separated by raised line extending from base to apical discal half, connecting pronotal halves and merging into them; anterior margin arcuate; posterior margin bisinuate; sides of pronotum convex before and after transverse constriction; lateral margins narrowly rimmed; posterolateral angles orthogonal; anterolateral angles slightly produced. Hypomeron finely microreticulate, widest in middle. Prosternum moderately long in front of procoxae, with anterior margin concave; sides raised around procoxae, forming carinae, not reaching anterior margin, prosternal process long, moderately broad and with posterior margin broadly rounded. Mesoventrite coarse, short and wide, with deep triangular groove for reception of prosternal process; posterior margin around mesocoxae raised. Metaventrite slightly wider than long, shiny with setigerous punctures; disc convex with very shallow to indistinct, medial, triangular depression in posterior half; discrimen in basal $2 / 3$, very thin, almost indistinct; prebasal foveae absent. Elytra (EL: 0.64-0.69 mm, EW: 0.52-0.54 mm) convex, widest in about middle; disc convex, sides strongly declivous; surface shiny, with tiny punctures; elytral margin narrowly rimmed; humeri feebly developed; epipleuron tapering posteriorly. Prominent carina on sixth interval reaching $4 / 5$ of elytron; strial punctures absent. Scutellum subovate, flat. Legs moderately long; femora clavate; tibiae longest. Protibiae with anterior cleaning fringe on apical $1 / 3$; 
mesotibiae with two cleaning fringes - anterior on apical $1 / 5$ and posterior on apical $1 / 3$; metatibiae with posterior cleaning fringe on apical $1 / 3$. Tarsi 5 -segmented, first four segments each with one fine pale, recumbent seta, fifth segment slightly shorter than remaining segments combined; claws with a large subbasal and smaller basal teeth.
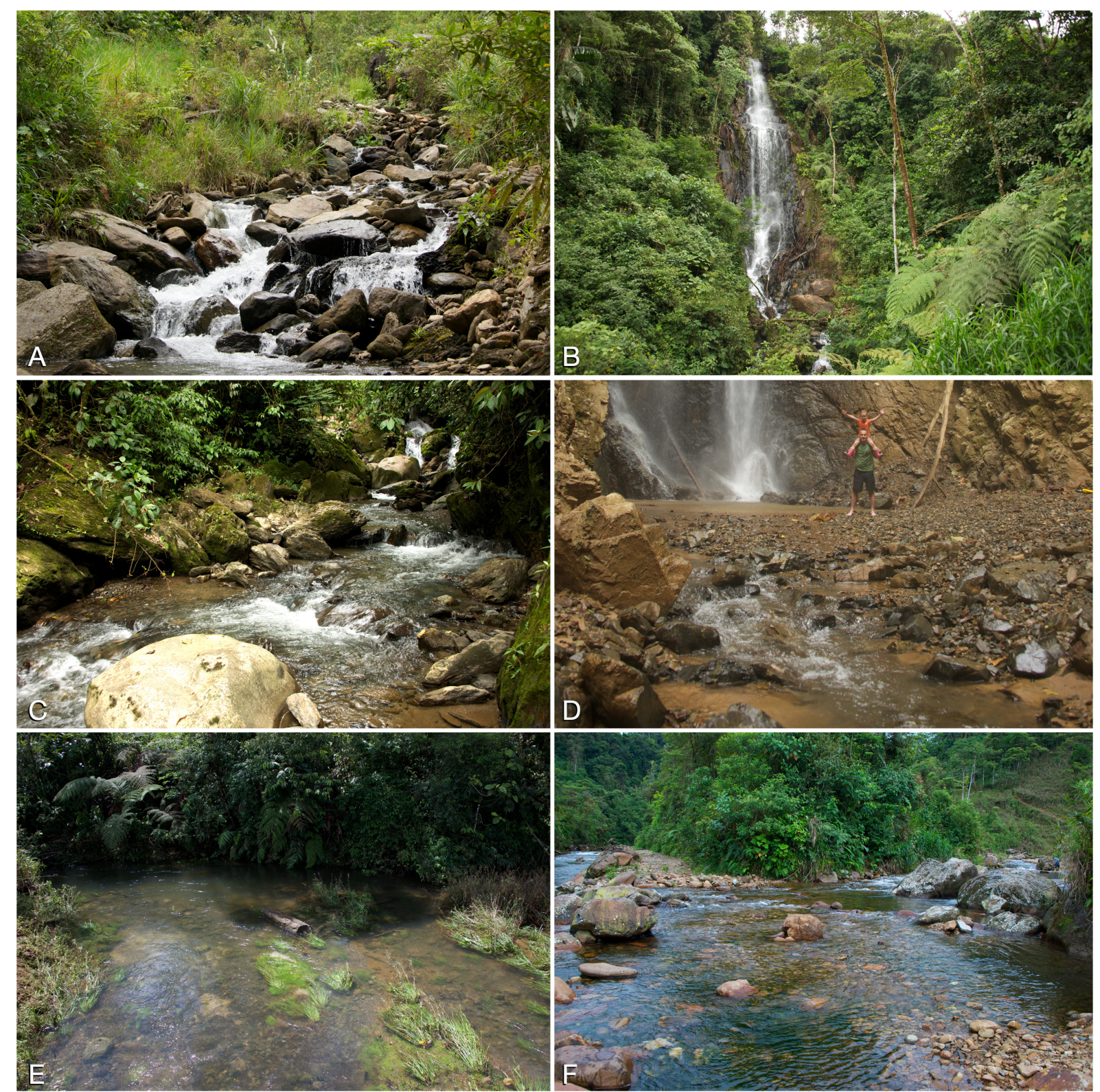

Fig. 11. Sampling sites for Onychelmis spp. in Ecuador. A. Morona-Santiago Prov., Limon env., Rio Yungantza, 02 ${ }^{\circ} 59^{\prime} 49.3^{\prime \prime} \mathrm{S}, 78^{\circ} 29^{\prime} 18.9^{\prime \prime} \mathrm{W}, 1522 \mathrm{~m}$ a.s.l. B. Napo Prov., road to Coca, 00 $43^{\prime} 39.6^{\prime \prime} \mathrm{S}$,

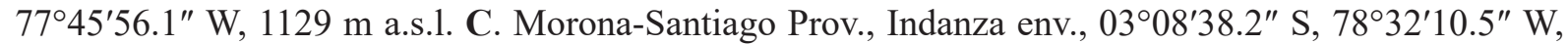
1299 m a.s.l. D. Morona-Santiago Prov., Santa Rosa de Mamanguy env., Cascada la Encañada,

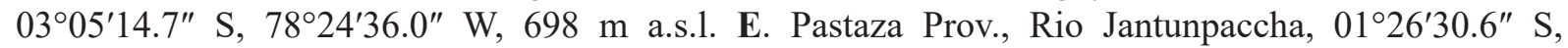

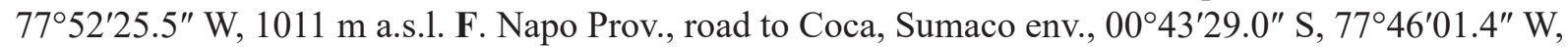
1109 m a.s.l. 
AвDomen. With 5 ventrites. First ventrite with basal margin broadly rounded; fifth ventrite longest, apically setose, with posterior margin broadly arcuate. Aedeagus (Fig. 10C-D) elongate. Penis without fibula; corona in apical half; in ventral view concave, constricted before rounded apex with medial projection; in lateral view evenly narrowed from base to slightly curved apex. Parameres absent. Phallobase slightly longer than penis, parallel-sided, in ventral view straight, curved in lateral view.

\section{Female}

Externally similar to male, except fifth ventrite more elongate.

\section{Biology}

Collected from slowly flowing stream ca $7 \mathrm{~m}$ wide with submerged vegetation, sparse larger stones and deep layer of fine gravel and sand (Fig. 11E).

\section{Distribution}

Known only from the type locality in Pastaza Province (Figs 11E, 12A-B).

\section{Discussion}

At first glance, the genus Onychelmis consists of small species with a uniform morphology. This could be part of the reason why only three species have been described so far, the most recent one almost 30 years ago (Jäch et al. 2016). Although representatives of the genus are reported in several recent studies from various regions (e.g., Amanzo et al. 2003; González-Córdoba et al. 2016; Reymundo \& Araujo 2016), they are mostly determined only to the genus or assigned to one of the three (most often O. leleupi) known species. Above all, this situation is most likely due to a lack of extensive material.
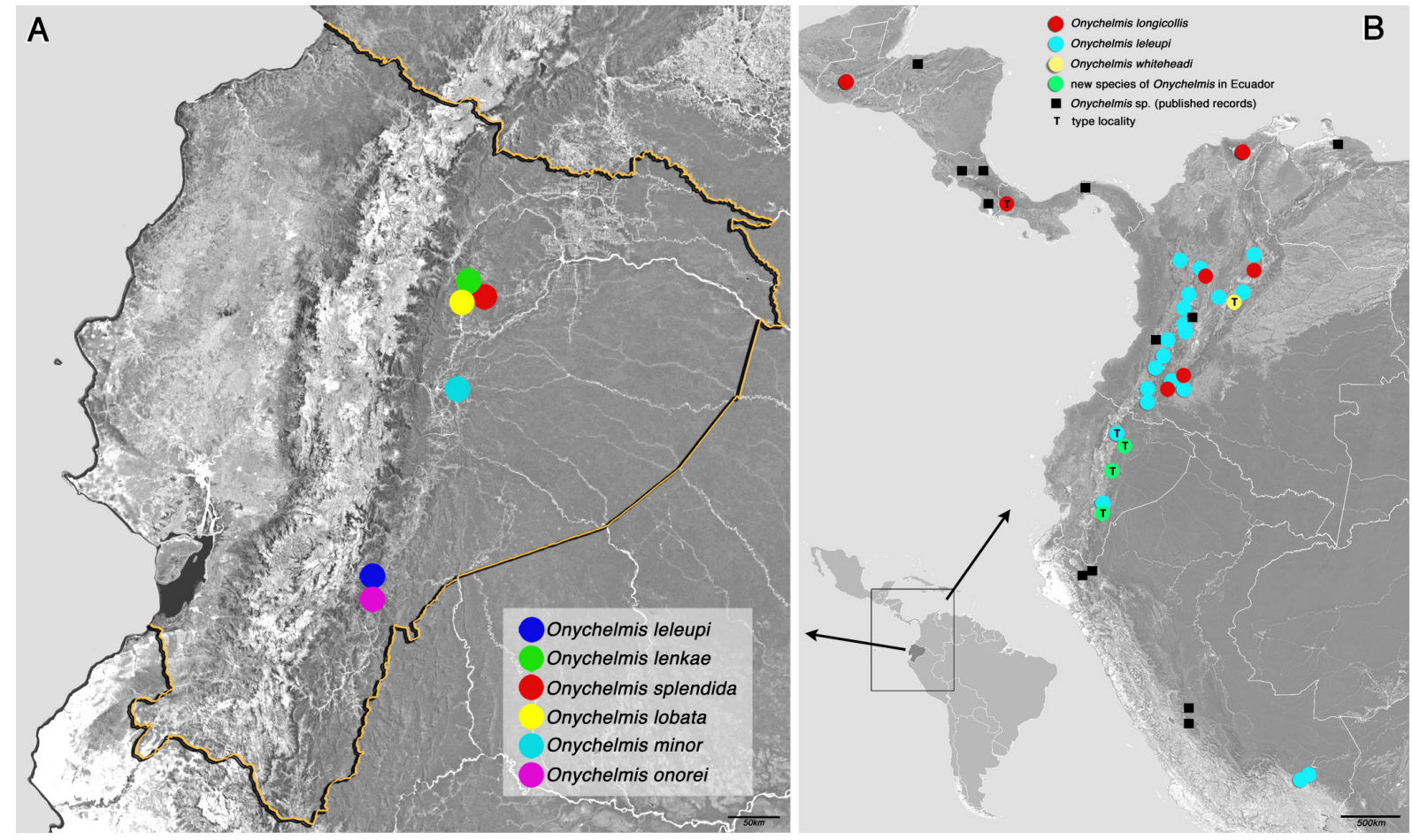

Fig. 12. Distribution map of Onychelmis Hinton, 1941. A. New species described within this study. B. Published records of Onychelmis and potential distribution of the genus. 
The situation was quite different concerning this revision. The available material, although not from a large geographical area, includes dozens of individuals from several locations. Besides, we had access to the type material of two of the three known species, as well as DNA barcoding data. The results of the revision of such material were diametrically opposed to the established concept of the genus' diversity.

Primarily, the data from DNA barcoding analysis revealed the surprising diversity of the genus. The discovered genetic variability was subsequently confirmed by morphological characters, allowing us to describe five new species. DNA-based methods thus proved to be particularly useful in providing a background for a better understanding of the species diversity. The results gained within the study also suggest that the real diversity of the genus is much higher. Significant genetic distances found between the species of Onychelmis support the likelihood of hidden diversity in the genus (as discussed in Tavares et al. 2011; Milá et al. 2012; Blagoev et al. 2013), which awaits discovery and description.

According to the maximum likelihood (ML) analysis (Fig. 1) based on COI data, the genus Onychelmis splits into two main clades; the first one is well-supported, and comprises $O$. splendida sp. nov. and $O$. lenkae sp. nov., the second clade includes the five remaining species that were analyzed (O. leleupi, $O$. lobata sp. nov., $O$. minor sp. nov., $O$. onorei sp. nov., $O$. sp.). The first group is externally similar and differs from the remaining species by the lanceolate structure of male genitalia. Due to the lack of more pronounced morphological differences and absence of COI data, we can only suggest that $O$. longicollis, with its smaller size and aedeagus of similar shape to that of $O$. lenkae sp. nov. and $O$. splendida sp. nov., could belong to this clade. Within the second clade, the ML analysis suggested another two groups, one with $O$. minor sp. nov. and an undetermined species from Panama, and a second with $O$. lobata sp. nov., $O$. onorei sp. nov. and $O$. leleupi. One of the characteristic features of this group may be the laterally projected apex of the penis; $O$. minor differs from $O$. leleupi, $O$. onorei sp. nov. and O. lobata sp. nov. by the small size and less widened subapical area of the penis. Based on the structure of the aedeagus, $O$. whiteheadi could also belong to the second group.

The structure of the male genitalia, together with the ML analysis, points to the presence of separate lineages in the genus; however, we found no other stable characters to support this division, and therefore refrain from proposing species groups or subgenera. With the use of DNA barcodes, we also identified larvae of few species of Onychelmis, and their external morphology varies strongly, which could be used to support the existence of these groups in the future. A detailed description of the determined larvae is the subject of another paper.

Externally, all species of Onychelmis are hardly distinguishable. We recorded differences in the body size, impression of elytral punctures, shape of humeri, presence of elytral carinae and extension of plastron on femora, but these characters can vary, and reliable determination often requires examination of the male genitalia. Femoral tomentum appears to be useful for the identification of similarly sized and otherwise externally uniform species. Although it is mostly species-specific, it differs between sexes and can sometimes overlap in some species. This character is usually clearly visible, but sometimes plastron scales can be brushed away, making this feature inapplicable for determination. Females tend to have a greater extension of plastron on legs than males. Although a small extension of plastron can be found on metafemora we focused on pro- and mesofemora only, which have proved to be more illustrative. Sexual dimorphism can also be seen on the length of the fifth ventrite, on metaventrite in presence of medial, triangular depression in posterior half, and in presence of the two prebasal foveae often accompanied by a tuft of setae. The characters on the metaventrite are best observable in lateral view.

The distribution of the genus was reconstructed based on our data and published information (Sharp 1882; Spangler \& Santiago 1991; Spangler \& Santiago-Fragoso 1992; Amanzo et al. 2003; García Obando 2003; Sites et al. 2003; Álvarez et al. 2011; Guevara Mora 2011; Llano-Castillo 2012; Maier 
2013; Salcedo et al. 2013; Tapia Castillo \& Vega 2014; Kohlmann et al. 2015; Shepard \& Chaboo 2015; González-Córdoba et al. 2016; Reymundo \& Araujo 2016; Rodríguez et al. 2016; Shepard pers. com.). Onychelmis is a montane genus dispersed along the Andes, so far known from Guatemala to southern Peru (Fig. 12B). Maier (2013) recorded the genus from the easternmost projection of the Andes in the north of Venezuela, which supports the hypothesis that Onychelmis is linked with this mountain range.

Species distribution, as shown here, must be taken with reasonable caution. Almost all previously reported specimens have been assigned to only two species, which corresponded with the presumed low diversity of the genus. However, as can be seen from the results presented in this revision, the species diversity is greatly underestimated. We recorded six species (five new to science) in Ecuador alone, and similar findings from other countries would not be surprising. This phenomenon of underestimated diversity can be seen in many Neotropical genera, such as Hexanchorus Sharp, 1882 (Maier 2013; Linský et al. 2019).

The most-reported species, O. leleupi, is distributed from Colombia to southern Peru based on published records. However, the southernmost specimens were females (Shepard, pers. com.), and the possibility that specimens from Peru represent a different species cannot be excluded. The type species of the genus, O. longicollis, has a more northern distribution, following Magdalena Valley in Colombia, and its occurrence in Central America is likely more recent. It is necessary to note that the male genitalia of the holotype of O. longicollis, depicted here for the first time (Fig. 7A-B), differ from those in Spangler \& Santiago (1991). Moreover, O. longicollis does not have elytral striae with punctures "very coarse, deep", and it is likely that Spangler \& Santiago (1991) studied another species. Although its size was not specified in Hinton (1941), the type species is smaller than most of the remaining congeners, which can be useful for its determination. The largest species of the genus, $O$. whiteheadi, is so far known only from the type locality and may represent local allopatric speciation, as may the new species described herein.

The proximity between Onychelmis and Notelmis Hinton, 1941 has been observed in the past (e.g., Jäch et al. 2016). Even Sharp (1882) noted the close similarity of the two species which are now the type species of the two genera. The genus Onychelmis differs in possessing subbasal teeth on the claws and an elytral carina is only found on the $6^{\text {th }}$ interval or it is completely reduced (vs elytral carinae on $6^{\text {th }}$ and $8^{\text {th }}$ intervals in Notelmis). Moreover, Onychelmis lacks parameres or has them integrated into the penis (sensu Delève 1968). Generally, at least in Phytophaga, the parameres remain outside the female body during copulation. They serve as a sensory organ for contacting the female or as a grasping organ for stabilization. Sensillae on the penis are responsible for finding the female genital opening and it is assumed that males without parameres require a penis with advanced sensillary equipment (Düngelhoef \& Schmitt 2010). An absence of parameres is a rare trait among Neotropical genera of riffle beetles. Out of 45 genera that have published illustrations of male genitalia, only four, Ictelmis Čiampor, Linský \& Čiamporová-Zat’ovičová, 2019, Epodelmis Hinton, 1973, Neolimnius Hinton, 1939 and Onychelmis, lack them. Although a reduction or complete loss of parameres could be a shared evolutionary feature, as it is in the tribe Macronychini (Jäch \& Boukal 1995), it does not seem to be true for the four mentioned genera. For example, the genus Epodelmis is undoubtedly more closely related to Holcelmis Hinton, 1973, or even to Hexacylloepus Hinton, 1940, than to any of the three mentioned genera. The loss of parameres could be a moderately rapid event, which could subsequently lead to the formation of a reproductive barrier and thus accelerate speciation.

According to the ML analysis (Fig. 1), the closest genus to Onychelmis is Ictelmis. Both genera share the presence of subbasal teeth on the claws, have similar pronota (Ictelmis with well-developed sublateral carinae), and lack parameres. The genus Ictelmis differs in having the pronotum with microreticulation 
(shiny in Onychelmis), rugose venter, and a unique form of elytron that has only seven elytral striae, likely due to the partial fusion of intervals.

Our study contributes to the knowledge of the Neotropical riffle beetles. We revised the genus, added five new species to the world Elmidae fauna, and showed very clearly the importance of using molecular data (DNA barcoding) in the taxonomy and systematics of the riffle beetles. Our results indicate that the Elmidae fauna of the Neotropics is still largely undescribed, and thus intensive and more detailed future research is required to understand its real diversity.

\section{Acknowledgements}

We wish to thank Prof. Giovanni Onore (PUCE), for his invaluable assistance and willingness during sample collecting. Our thanks are due to Malcolm D. Kerley (NHM) and Charyn J. Micheli (NMNH) for loaning type specimens, and to William D. Shepard (EMEC) for providing additional information on the distribution of the species of Onychelmis. We are also grateful to Thiago T.S. Polizei (MZSP) and an anonymous reviewer for their constructive suggestions to improve the manuscript. This study was partly supported by the VEGA project No. 2/0101/16 and Comenius University Grant No. UK/184/2019.

\section{References}

Álvarez L.F., Gil I.C., Villabona S.L., Ospina J.G., Posada J.A., Peláez E., Quijano M.A., Huiguita H.D., Rodríguez S.L., Goméz M.C., Muñoza E.M., Zapata C. \& Ocampo D. 2011. Estudios especificos que hacen parte del Estudio de Impacto ambiental del Proyecto hidroeléctrico del Río Chilí. Universidad Católica de Oriente, Rionegro, Colombia.

Amanzo J., Acosta R., Aguilar C., Eckhardt K., Baldeón S. \& Pequeño T. 2003. Evaluación biológica rápida del Santuario Nacional Tabaconas - Namballe y Zonas aledañas. Informe WWF-OPP: QM-91. World Wild Fund - Perú.

Barr C.B. 2018. Amazonopsis, an unusual new genus of riffle beetle from South America with two new species(Coleoptera,Elmidae, Elminae).ZooKeys 803:71-92.https://doi.org/10.3897/zookeys.803.28124

Blagoev G.A., Nikolova N.I., Sobel C.N. Hebert P.D.N \& Adamowicz S.J. 2013. Spiders (Araneae) of Churchill, Manitoba: DNA barcodes and morphology reveal high species diversity and new Canadian records. BMC Ecology 13: e44. https://doi.org/10.1186/1472-6785-13-44

Cayrou J., Compin A., Giani N. \& Céréghino R. 2000. Associations spécifiques chez les macroinvertébrés benthiques et leur utilisation pour la typologie des cours d'eau. Cas du réseau hydrographique AdourGaronne (France). International Journal of Limnology 36 (3): 189-202.

https://doi.org/10.1051/limn/2000017

Čiampor Jr F., Laššová K., Maier C.A., Čiamporová-Zat'ovičová Z. \& Kodada J. 2016. Phanoceroides Hinton, 1939: description of new species, morphology of larvae, and revised taxonomic position of the genus (Coleoptera: Elmidae) based on molecular evidence. Zootaxa 4117 (2): 277-288.

https://doi.org/10.11646/zootaxa.4117.2.9

Čiampor Jr F., Linský M. \& Čiamporová-Zatovičová Z. 2019. Ictelmis, a new riffle beetle genus from Ecuador (Coleoptera: Elmidae) Zootaxa 4695 (5): 483-491. https://doi.org/10.11646/zootaxa.4695.5.5

Compin A. \& Céréghino R. 2003. Sensitivity of aquatic insect species richness to disturbance in the Adour-Garonne stream system (France). Ecological Indicators 3: 135-142.

https://doi.org/10.1016/S1470-160X(03)00016-5

Darriba D., Taboada G.L., Doallo R. \& Posada D. 2012. jModelTest 2: more models, new heuristics and parallel computing. Nature Methods 9 (8): 772. https://doi.org/10.1038/nmeth.2109 
Delève J. 1968. Coleoptera Elminthidae. In: Leleup N. (ed.) Mission zoologique belge aux Îles Galapagos et en Ecuador (N. et J. Leleup, 1964-1965). Resultats scientifiques 1: 211-272. Institut Royal des Sciences Naturelles de Belgique, Brussels.

Düngelhoef S. \& Schmitt M. 2010. Genital feelers: the putative role of parameres and aedeagal sensilla in Coleoptera Phytophaga (Insecta). Genetica 138: 45-57. https://doi.org/10.1007/s10709-009-9404-9

Folmer O., Black M., Hoeh W., Lutz R. \& Vrijenhoek R. 1994. DNA primers for amplification of mitochondrial cytochrome c oxidase subunit I from diverse metazoan invertebrates. Molecular Marine Biology and Biotechnology 3: 294-299.

García Obando L.A. 2003. Indicadores técnicos y Evaluación de la Influencia del uso de la Tierra en la Calidad del Agua, Subcuenca del Río Tascalapa Yoro, Honduras. Master's thesis, CATIE, Turrialba.

González-Córdoba M., Zúñiga M.C., Manzo V., Giraldo L.P. \& Chará J. 2016. Notelmis Hinton y Onychelmis Hinton (Coleoptera: Elmidae: Elminae) de Colombia: Claves taxonómicas ilustradas. Boletín del Museo de Entomología de la Universidad del Valle 16 (2): 1-17.

Guevara Mora M. 2011. Insectos acuáticos y calidad del agua en la cuenca y embalse del río Peñas Blancas, Costa Rica. Revista de Biología tropical 59: 635-654. https://doi.org/10.15517/rbt.v0i0.3129

Hayashi M., Song S.D. \& Sota T. 2013. Patterns of hind-wing degeneration in Japanese riffle beetles (Coleoptera: Elmidae). European Journal of Entomology 110 (4): 689-697.

https://doi.org/10.14411/eje.2013.092

Hinton H.E. 1941. New genera and species of Elmidae (Coleoptera). Transactions of the Royal Entomological Society of London 91 (3): 65-104. https://doi.org/10.1111/j.1365-2311.1941.tb01044.x

Jäch M.A. \& Boukal D.S. 1995. Elmidae: 2. Notes on Macronychini, with descriptions of four new genera from China (Coleoptera). In: Jäch M.A. \& Ji L. (eds) Water Beetles of China. Vol. I: 299-323. Zoologisch-Botanische Gesellschaft in Österreich und Wiener Coleopterologenverein, Vienna.

Jäch M.A., Kodada J., Brojer M., Shepard W.D. \& Čiampor Jr F. 2016. Coleoptera: Elmidae and Protelmidae. World Catalogue of Insects, 14, XXI. Brill, Leiden. https://doi.org/10.1163/9789004291775

Kodada J., Jäch M.A. \& Čiampor Jr F. 2016. 19.2 Elmidae Curtis, 1830. In: Beutel R.G. \& Leschen R.A.B. (eds) Handbook of Zoology, Arthropoda: Insecta, Coleoptera, Beetles Volume 1: Morphology and Systematics (Archostemata, Adephaga, Myxophaga, Polyphaga partim) (2 ${ }^{\text {nd }}$ Ed.): 561-589. Walter de Gruyter GmbH, Berlin/Boston.

Kohlmann B., Arroyo A., Springer M. \& Vásquez D. 2015. Agrorural ecosystem effects on the macroinvertebrate assemblages of a tropical river. In: Blanco J.A. (ed.) Biodiversity in Ecosystems Linking Structure and Function: 317-351. InTechOpen. https://doi.org/10.5772/59073

Kumar S., Stecher G., Li M., Knyaz C. \& Tamura K. 2018. MEGA X: Molecular Evolutionary Genetics Analysis across computing platforms. Molecular Biology and Evolution 35: 1547-1549. https://doi.org/10.1093/molbev/msy096

Linský M., Čiamporová-Zat’ovičová Z. \& Čiampor Jr F. 2019. Four new species of Hexanchorus Sharp from Ecuador (Coleoptera, Elmidae) with DNA barcoding and notes on the distribution of the genus. ZooKeys 838: 85-109. https://doi.org/10.3897/zookeys.838.33086

Llano-Castillo C. 2012. Respuesta de los Macroinvertebrados bentónicos a las Condiciones de Calidad de Agua en el Tramo medio-alto del Río Felidia, Cuenca del Río Cali, Valle del Cauca-Colombia. Trabajo de Grado. Universidad Autónoma de Occidente, Santiago de Cali, Colombia.

Maier C.A. 2013. A revision of the Larainae (Coleoptera, Elmidae) of Venezuela, with description on nine new species. ZooKeys 329: 33-91. https://doi.org/10.3897/zookeys.329.4961 
Manzo V. \& Archangelsky M. 2015. Austrelmis Brown (Coleoptera: Byrrhoidea: Elmidae) from Argentina: five new species. Zootaxa 4058 (3): 403-416. https://doi.org/10.11646/zootaxa.4058.3.7

Martínez-Román N.R., Manzo V. \& Archangelsky M. 2019. A new species of Stethelmis Hinton (Coleoptera: Elmidae) from Argentina and description of its larva. Anais da Academia Brasileira de Ciências 91 (4): e20180954. https://doi.org/10.1590/0001-3765201920180954

Milá B., Tavares E.S., Muñoz Saldaña A., Karubian J., Smith T.B. \& Baker A.J. 2012. A TransAmazonian screening of mtDNA reveals deep intraspecific divergence in forest birds and suggests a vast underestimation of species diversity. PLoS One 7 (7): e40541.

https://doi.org/10.1371/journal.pone.0040541

Monte C. \& Mascagni A. 2012. Review of the Elmidae of Ecuador with the description of ten new species (Coleoptera: Elmidae). Zootaxa 3342 (1): 1-38. https://doi.org/10.11646/zootaxa.3342.1.1

Passos M., Miranda G. \& Nessimian J. 2015. Three new species of Macrelmis Motschulsky (Coleoptera: Elmidae: Elminae) from Southeastern Brazil with new definition of species groups to the genus. Zootaxa 4058 (2): 195-210. https://doi.org/10.11646/zootaxa.4058.2.3

Polizei T.T.S. \& Barclay M.V.L. 2018. The genus Hintonelmis (Coleoptera: Elmidae: Elminae), new species and records. Journal of Natural History 52 (45-46): 2949-2959.

https://doi.org/10.1080/00222933.2018.1560512

Polizei T.T.S. \& Barclay M.V.L. 2019. The genus Cylloepus Erichson, 1847 (Coleoptera: Elmidae: Elminae) new species and combinations. Zootaxa 4652 (1): 93-100.

https://doi.org/10.11646/zootaxa.4652.1.3

Polizei T.T.S., Barclay M.V.L. \& Bispo P.C. 2020. Hexacylloepus Hinton, 1940 rises again; 18 new species of a neglected genus (Coleoptera: Byrrhoidea: Elmidae). Zootaxa 4819 (1): 6-48.

https://doi.org/10.11646/zootaxa.4819.1.2

Reymundo J.I.S \& Araujo A.A.H. 2016. Distribución espacial de Ephemeroptera, Plecoptera, Trichoptera y Coleoptera (Insecta) en una quebrada de primer orden, bosque montano, Junín, Perú. Revista peruana de Biología 23 (2): 95-102. https://doi.org/10.15381/rpb.v23i2.12377

Rodríguez J.M.W., Rojas J.M.C. \& Gómez J.H.C. 2016. Ensamble de macroinvertebrados acuáticos y estado ecológico de la microcuenca Dalí-Otún, Departamento de Risaralda, Colombia. Hidrobiológica 26 (3): 359-371.

Salcedo S., Artica L. \& Trama F.A. 2013. Macroinvertebrados bentónicos como indicadores de la calidad de agua en la microcuenca San Alberto, Oxapampa, Perú. Apuntes de Ciencia \& Sociedad 3 (2): 124-139. https://doi.org/10.18259/acs.2013016

Sharp D. 1882. Insecta, Coleoptera: Haliplidae, Dytiscidae, Gyrinidae, Hydrophilidae, Heteroceridae, Parnidae, Georissidae, Cyathoceridae. Biologia Centrali-Americana 1 (2): 1-144.

Shepard W.D. \& Barr C. 2016. Neoelmis guarani Shepard \& Barr, a sexually dimorphic new species from Paraguay (Insecta: Coleoptera: Elmidae: Elminae). Zootaxa 4083 (3): 418-430.

https://doi.org/10.11646/zootaxa.4083.3.6

Shepard W.D. \& Chaboo C.S. 2015. Beetles (Coleoptera) of Peru: A Survey of the Families. Elmidae. Journal of the Kansas Entomological Society 88 (2): 167-168.

https://doi.org/10.2317/kent-88-02-167-168.1

Sites R.W., Willig M.R. \& Linit M.J. 2003. Macroecology of aquatic insects: a quantitative analysis of taxonomic richness and composition in the Andes Mountains of Northern Ecuador. Biotropica 35 (2): 226-239. https://doi.org/10.1111/j.1744-7429.2003.tb00282.x 
Spangler P. \& Santiago S. 1991. A new species and new records from Colombia of the water beetle genus Onychelmis Hinton (Coleoptera: Elmidae: Elminae). Proceedings of the Entomological Society of Washington 93 (2): 495-498.

Spangler P. \& Santiago-Fragoso S. 1992. The aquatic beetle subfamily Larainae (Coleoptera: Elmidae) in Mexico, Central America and the West Indies. Smithsonian Contributions to Zoology 528: 1-74. https://doi.org/10.5479/si.00810282.528

Tapia Castillo M. \& Vega J.A.B. 2014. Diversidad y estructura de la comunidad de macroinvertebrados acuáticos como indicadores de la calidad del agua del río Chiriquí Viejo, Chiriquí, Panamá. Sciencita (Panamá) 24 (2): 93-106.

Tavares E.S., Gonçalves P., Miyaki C.Y. \& Baker A.J. 2011. DNA barcode detects high genetic structure within Neotropical bird species. PLoS One 6 (12): e28543.

https://doi.org/10.1371/journal.pone.0028543

Manuscript received: 22 July 2020

Manuscript accepted: 14 December 2020x

Published on: 11 March 2021

Topic editor: Nesrine Akkari

Section editor: Max Barclay

Desk editor: Radka Rosenbaumová

Printed versions of all papers are also deposited in the libraries of the institutes that are members of the EJT consortium: Muséum national d'histoire naturelle, Paris, France; Meise Botanic Garden, Belgium; Royal Museum for Central Africa, Tervuren, Belgium; Royal Belgian Institute of Natural Sciences, Brussels, Belgium; Natural History Museum of Denmark, Copenhagen, Denmark; Naturalis Biodiversity Center, Leiden, the Netherlands; Museo Nacional de Ciencias Naturales-CSIC, Madrid, Spain; Real Jardín Botánico de Madrid CSIC, Spain; Zoological Research Museum Alexander Koenig, Bonn, Germany; National Museum, Prague, Czech Republic. 